\title{
UK Renal Registry 14th Annual Report: Chapter 8 Haemoglobin, Ferritin and Erythropoietin amongst UK Adult Dialysis Patients in 2010: National and Centre-Specific Analyses
}

\author{
Lynsey Webb ${ }^{a}$, Julie Gilg ${ }^{a}$, Martin Wilkie ${ }^{b}$

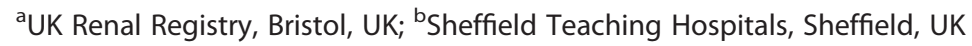

\section{Key Words}

Anaemia · Chronic kidney disease · Dialysis - End stage renal disease · Epidemiology · Erythropoietin - Erythropoietin Stimulating Agent - European Best Practice Guidelines . Ferritin - Haemodialysis - Haemoglobin - NICE - Peritoneal dialysis · Renal Association

\begin{abstract}
Background: The UK Renal Association (RA) and National Institute for Health and Clinical Excellence (NICE) have published clinical practice guidelines which include recommendations for management of anaemia in established renal failure. Aim: To determine the extent to which the guidelines for anaemia management are met in the UK. Methods: Quarterly data were obtained regarding haemoglobin $(\mathrm{Hb})$ and factors that influence $\mathrm{Hb}$ from renal centres in England, Wales, Northern Ireland (EWNI) and the Scottish
\end{abstract}

Renal Registry for the incident and prevalent renal replacement therapy (RRT) cohorts for 2010. Results: In the UK, in $201053.6 \%$ of patients commenced dialysis therapy with $\mathrm{Hb} \geqslant 10.0 \mathrm{~g} / \mathrm{dl}$ (median $\mathrm{Hb} 10.1 \mathrm{~g} / \mathrm{dl}$ ). The median $\mathrm{Hb}$ of haemodialysis (HD) patients was $11.5 \mathrm{~g} / \mathrm{dl}$ with an interquartile range (IQR) of $10.5-12.3 \mathrm{~g} / \mathrm{dl}$. Of $\mathrm{HD}$ patients $84.6 \%$ had $\mathrm{Hb} \geqslant 10.0 \mathrm{~g} / \mathrm{dl}$. The median $\mathrm{Hb}$ of peritoneal dialysis (PD) patients in the UK was $11.6 \mathrm{~g} / \mathrm{dl}$ (IQR 10.6$12.5 \mathrm{~g} / \mathrm{dl}$ ). Of UK PD patients, $87.2 \%$ had $\mathrm{Hb} \geqslant 10.0 \mathrm{~g} / \mathrm{dl}$. The median ferritin in HD patients in EWNI was $444 \mu \mathrm{g} / \mathrm{L}$ (IQR 299-635) and 96\% of HD patients had a ferritin $\geqslant 100 \mu \mathrm{g} / \mathrm{L}$. The median ferritin in PD patients was $264 \mu \mathrm{g} / \mathrm{L}$ (IQR $148-426$ ) with $86 \%$ of PD patients having a ferritin $\geqslant 100 \mu \mathrm{g} / \mathrm{L}$. In EWNI the mean Erythropoietin Stimulating Agent (ESA) dose was higher for HD than PD patients (9,020 vs. 6,202 IU/week). Conclusions: Of prevalent $\mathrm{HD}$ patients, $52.7 \%$ had $\mathrm{Hb} \geqslant 10$ and $\leqslant 12 \mathrm{~g} / \mathrm{dl}$. Of prevalent PD patients, $54.3 \%$ had Hb $10.5-12.5 \mathrm{~g} / \mathrm{dl}$. 


\section{Introduction}

This chapter describes UK Renal Registry (UKRR) data relating to the management of anaemia in dialysis patients during 2010. The chapter reports outcomes of submitted variables and analyses of these variables in the context of established guidelines and recommendations.

The renal National Service Framework (NSF) part one [1] and the RA minimum standards document 3rd edition [2] state that individuals with chronic kidney disease $(\mathrm{CKD})$ should achieve a haemoglobin $(\mathrm{Hb})$ of at least $10 \mathrm{~g} / \mathrm{dl}$ within 6 months of being seen by a nephrologist, unless there is a specific reason why it was unachievable. At present the UKRR does not collect $\mathrm{Hb}$ measurements specifically from patients 6 months after meeting a nephrologist. However an indication of the attainment of this standard is given by the $\mathrm{Hb}$ of the incident patient population (i.e. the $\mathrm{Hb}$ at the start of dialysis). The achievement of these standards is mainly through the use of iron therapy (oral and intravenous) and Erythropoietin Stimulating Agents (ESAs).

The risks associated with low $(<10 \mathrm{~g} / \mathrm{dl})$ and high $(>13 \mathrm{~g} / \mathrm{dl}) \mathrm{Hb}$ are not necessarily equivalent. The European Best Practice Guidelines (EBPG) [3] set a minimum target of $11 \mathrm{~g} / \mathrm{dl}$ but suggest not to go higher than $12 \mathrm{~g} / \mathrm{dl}$ in severe cardiovascular disease. The United States Kidney Disease Outcomes Quality Initiative (KDOQI) [4] guidelines set a target $\mathrm{Hb}$ range of $11-12 \mathrm{~g} / \mathrm{dl}$ with a recommendation that the $\mathrm{Hb}$ target should not be greater than $13.0 \mathrm{~g} / \mathrm{dl}$. The NICE guidelines published in 2006 [5] and the 4th edition of the RA Clinical Practice Guidelines 2006 [6] recommended an outcome $\mathrm{Hb}$ of between 10.5 and $12.5 \mathrm{~g} / \mathrm{dl}$ (with ESA dose changes considered at 11 and $12 \mathrm{~g} / \mathrm{dl}$ ) which allows for the difficulty in consistently narrowing the distribution to between 11 and $12 \mathrm{~g} / \mathrm{dl}$. In 2009, a new target $\mathrm{Hb}$ range for haemodialysis (HD) patients was recommended by the 5th edition of the Renal Association Guidelines for Haemodialysis patients [7]. This guidance specified that pre-HD $\mathrm{Hb}$ concentration should be maintained between 10 and $12 \mathrm{~g} / \mathrm{dl}$. As this chapter analyses 2010 data, HD patients have been compared against this revised target.

The 5th edition of the UK Renal Association's Anaemia in CKD guideline [8] was published at the end of 2010 and attempted to unify targets with those published in the 2010 update NICE guideline on anaemia management in CKD [9]. The target outcome $\mathrm{Hb}$ for RRT patients on ESA treatment in these guidelines is between
10 and $12 \mathrm{~g} / \mathrm{dl}$. Therefore next year's report will use this standard for peritoneal dialysis (PD) and transplant patients on ESA therapy. The KDIGO website [10] is a useful resource for comparison of international anaemia guidelines.

The analyses in this chapter examine how centres comply with the 10-12 g/dl range (HD patients), 10.5$12.5 \mathrm{~g} / \mathrm{dl}$ range (PD patients) and the attainment of the minimum standard of $\mathrm{Hb} \geqslant 10.0 \mathrm{~g} / \mathrm{dl}$.

The national and international recommendations for target iron status in CKD used in this chapter remain unchanged from the 2006 UKRR Annual Report. The 2007 Renal Association (RA) Clinical Practice Guidelines Document, revised European Best Practice Guidelines (EBPGII), Dialysis Outcomes Quality Initiative (DOQI) guidelines and UK NICE anaemia guidelines all recommend a target serum ferritin greater than $100 \mu \mathrm{g} / \mathrm{L}$ and percentage transferrin saturation (TSAT) of more than $20 \%$ in patients with CKD. RA guidelines and EBPGII recommend hypochromic red cells (HRC) less than 10\%. In addition, EBPGII recommends a target reticulocyte $\mathrm{Hb}$ content $(\mathrm{CHr})$ of greater than $29 \mathrm{pg} /$ cell. KDOQI recommends a serum ferritin $>200 \mu \mathrm{g} / \mathrm{L}$ for HD patients. The NICE guidelines suggest that a hypochromic red cell value $>6 \%$ suggests ongoing iron deficiency.

To achieve adequate iron status across a patient population, RA guidelines and EBPGII advocate population target medians for ferritin of $200-500 \mu \mathrm{g} / \mathrm{L}$, for TSAT of $30-40 \%$, for hypochromic red cells of $<2.5 \%$ and $\mathrm{CHr}$ of $35 \mathrm{pg} / \mathrm{cell}$. EBPGII comments that a serum ferritin target for the treatment population of $200-500 \mu \mathrm{g} / \mathrm{L}$ ensures that $85-90 \%$ of patients attain a serum ferritin of $100 \mu \mathrm{g} / \mathrm{L}$.

All guidelines advise that serum ferritin levels should not exceed $800 \mu \mathrm{g} / \mathrm{L}$ since the potential risk of toxicity increases without conferring additional benefit. The KDOQI and NICE guidelines advise against intravenous iron administration to patients with a ferritin $>500 \mu \mathrm{g} / \mathrm{L}$.

Serum ferritin has some disadvantages as an index of iron status. It measures storage iron rather than available iron, behaves as an acute phase reactant and is therefore increased in inflammatory states, malignancy and liver disease and may not accurately reflect iron stores if measured within a week of the administration of intravenous iron. Of the alternative measures of iron status available, HRC and $\mathrm{CHr}$ are generally considered superior to TSAT. Both however require specialised analysers to which not all UK renal centres have easy access. Since TSAT is measured infrequently in many centres and 
most UK centres continue to use serum ferritin for routine iron management, ferritin remains the chosen index of iron status for this report.

\section{Methods}

The incident and prevalent RRT cohorts for 2010 were analysed. The UKRR extracted quarterly data electronically from renal centres in England, Wales and Northern Ireland; data from Scotland were provided by the Scottish Renal Registry. Patients receiving dialysis on 31st December 2010 were included in the prevalent analysis if they had been on the same modality of dialysis in the same centre for 3 months. The last available measurement of $\mathrm{Hb}$ from each patient from the last two quarters of 2010 was used for analysis. Patients were analysed as a complete cohort and also divided by modality into groups.

For the incident patient analyses, data from the first quarter after starting dialysis were used. Patients commencing RRT on $\mathrm{PD}$ or HD were included. Those receiving a pre-emptive transplant were excluded.

The last available ferritin measurement was taken from the last three quarters of the year and analysed for prevalent patients. Scotland is excluded from the analysis as data regarding ferritin is not included in its return.

The completeness of data items was analysed at both centre and country level. As in previous years all patients were included in analyses but centres with less than $50 \%$ completeness were excluded from the caterpillar and funnel plots showing centre performance. Centres providing relevant data from less than 20 patients were also excluded from the plots. The number preceding the centre name in each figure indicates the percentage of missing data for that centre.

The data were analysed to calculate summary statistics. These were maximum, minimum and average (mean and median) values. Standard deviations and inter-quartile ranges (IQR) were also calculated. These data are represented as caterpillar plots showing median values and quartile ranges.

The percentage achieving RA and other standards was calculated for $\mathrm{Hb}$. The percentage of patients achieving serum ferritin $\geqslant 100 \mu \mathrm{g} / \mathrm{L}, \geqslant 200 \mu \mathrm{g} / \mathrm{L}$ and $\geqslant 800 \mu \mathrm{g} / \mathrm{L}$ were also calculated. These are represented as caterpillar plots with 95\% confidence intervals (CIs) shown.

Longitudinal analysis was performed to calculate overall changes in achievement of standards from 1998 to 2010.

The UK RA Clinical Practice [2, 6] and NICE [5] guidelines in operation at the time these data were collected were as follows:

Patients with CKD should achieve a $\mathrm{Hb}$ of at least $10 \mathrm{~g} / \mathrm{dl}$ within 6 months of being seen by a nephrologist, unless there is a specific reason why it could not be achieved.

Patients with CKD treated with RRT should have a $\mathrm{Hb}$ of between 10.5 and $12.5 \mathrm{~g} / \mathrm{dl}$.

Patients with CKD should have a serum ferritin greater than $100 \mu \mathrm{g} / \mathrm{L}$ and percentage transferrin saturation (TSAT) of more than $20 \%$.

Serum ferritin levels in patients with CKD should not exceed $800 \mu \mathrm{g} / \mathrm{L}$.

Anaemia Management in UK Dialysis Patients
For the target $\mathrm{Hb}$ range in haemodialysis patients the standard specified by the 5th UK RA Clinical Practice Haemodialysis guideline [7] was used, which specifies:

Haemodialysis patients should have a pre-dialysis $\mathrm{Hb}$ concentration between 10 and $12 \mathrm{~g} / \mathrm{dl}$.

Data regarding ESAs were collected from all renal centres. Erythropoietin data from the last quarter of 2010 were used. Scotland was excluded from the analysis as data regarding ESA was not included in its return. Centres were excluded if there was $<90 \%$ completeness of ESA data. Centres reporting fewer than $70 \%$ of HD patients or fewer than $50 \%$ of PD patients treated with ESAs were considered to have incomplete data and were also excluded from further analysis. It is recognised that these exclusion criteria are relatively arbitrary but they are in part based upon the frequency distribution graph of centres' ESA use. The percentage of patients on ESAs is calculated from these data and incomplete data returns risk seriously impacting on any conclusions drawn.

Data are presented as weekly erythropoietin dose. Doses of darbepoietin were harmonised with erythropoietin data by multiplying by 200 and correcting for frequency of administration less than weekly. No adjustments were made with respect to route of administration.

The ESA data were collected electronically from renal IT systems but in contrast to laboratory linked variables the ESA dose required manual data entry. The reliability depended upon who entered the data, whether the entry was linked to the prescription or whether the prescriptions were provided by the primary care physician. In the latter case, doses may not be as reliably updated as the link between data entry and prescription is indirect.

\section{Results}

\section{Haemoglobin}

Haemoglobin in incident dialysis patients

The $\mathrm{Hb}$ at the time of starting RRT gives the only indication of concordance with current anaemia management recommendations in the pre-dialysis (CKD 5 - not yet on dialysis) group.

Patients for conservative care of established renal failure were by definition excluded from the dataset. Patients were similarly excluded if they received a pre-emptive transplant. In the future the UKRR hopes to collect and report CKD 5 data from patients who subsequently commence RRT and for those managed conservatively.

The percentage of data returned and outcome $\mathrm{Hb}$ are listed in table 8.1. Twelve centres are not included in this analysis due to either being small centres who submitted data on fewer than 20 patients and/or because data completeness was less than $50 \%$.

The median $\mathrm{Hb}$ of patients at the time of starting dialysis in the UK was $10.1 \mathrm{~g} / \mathrm{dl}$ with $53.6 \%$ of patients

Nephron Clin Pract 2012;120(suppl 1):c145-c174 
Table 8.1. Haemoglobin data for new patients starting haemodialysis or peritoneal dialysis during 2010

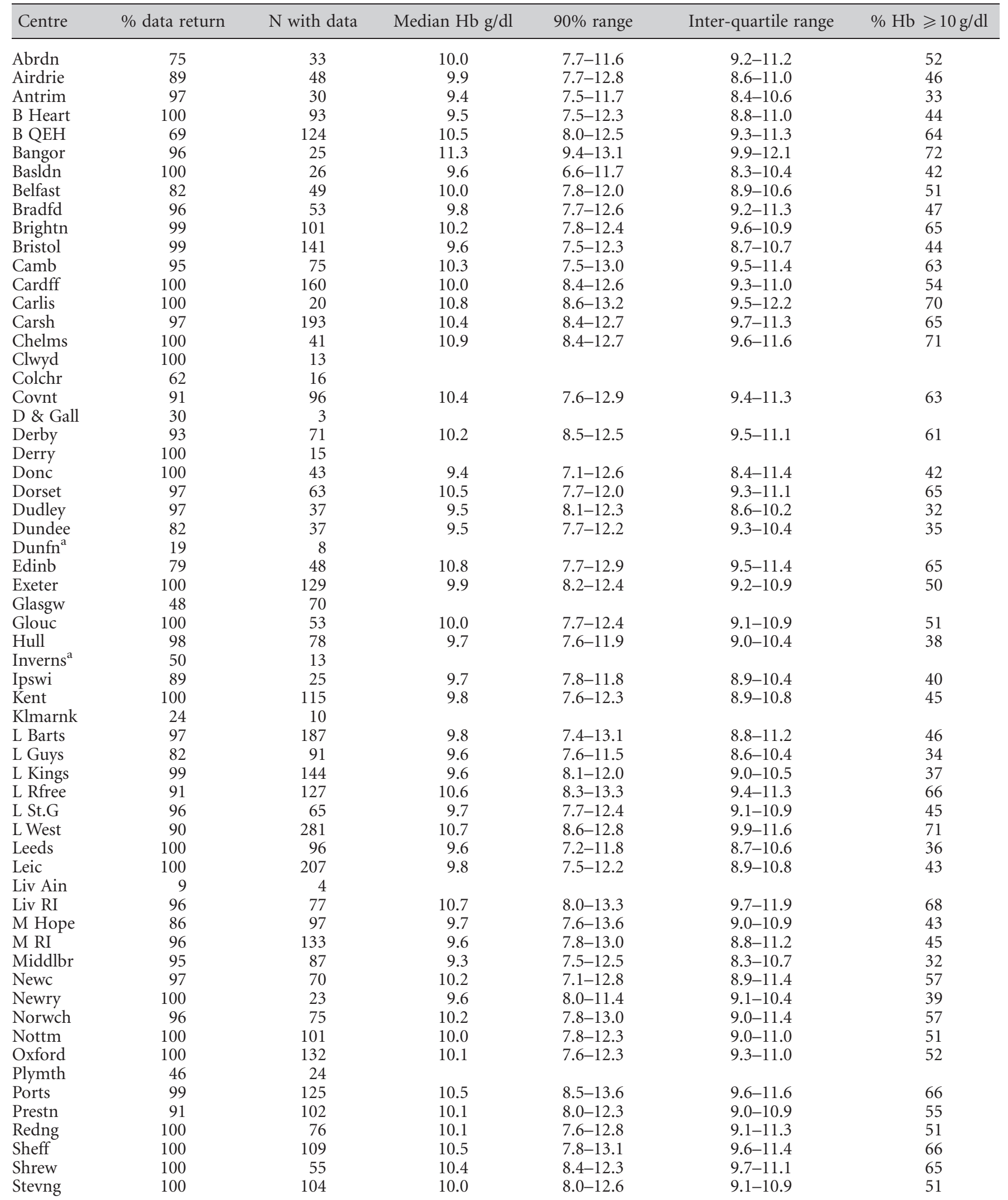


Table 8.1. Continued

\begin{tabular}{|c|c|c|c|c|c|c|}
\hline Centre & $\%$ data return & $\mathrm{N}$ with data & Median $\mathrm{Hb}$ g/dl & $90 \%$ range & Inter-quartile range & $\% \mathrm{Hb} \geqslant 10 \mathrm{~g} / \mathrm{dl}$ \\
\hline Sthend & 100 & 27 & 10.3 & $8.0-12.4$ & $9.1-11.6$ & 56 \\
\hline Stoke & 100 & 89 & 10.5 & $7.9-13.4$ & $9.5-11.6$ & 63 \\
\hline Swanse & 99 & 122 & 10.4 & $8.2-12.6$ & $9.4-11.3$ & 64 \\
\hline Truro & 100 & 39 & 10.2 & $8.0-13.6$ & $9.2-11.6$ & 59 \\
\hline Tyrone & 91 & 10 & & & & \\
\hline Wolve & 99 & 96 & 10.5 & $7.6-14.3$ & $9.0-11.8$ & 61 \\
\hline Wrexm & 100 & 23 & 11.5 & $8.9-13.6$ & $10.9-12.3$ & 83 \\
\hline York & 100 & 28 & 9.9 & $7.4-11.6$ & $8.9-11.1$ & 43 \\
\hline England & 94 & 4,535 & 10.1 & $7.7-12.7$ & $9.1-11.1$ & 54 \\
\hline N Ireland & 92 & 146 & 9.7 & $7.6-11.7$ & $8.9-10.6$ & 43 \\
\hline Scotland $^{\mathrm{a}}$ & 57 & 270 & 9.9 & $7.5-12.6$ & $8.7-11.2$ & 49 \\
\hline
\end{tabular}

Blank cells = centres excluded from analyses due to poor data completeness or low patient numbers

${ }^{a}$ A data extraction problem resulted in the UKRR not collecting all available data for these centres. The Scottish Renal Registry (www.srr.scot.nhs.uk <http://www.srr.scot.nhs.uk/>) record data completeness $>90 \%$ for both centres and also for Scotland as a whole

having a $\mathrm{Hb} \geqslant 10.0 \mathrm{~g} / \mathrm{dl}$ (vs. $10.2 \mathrm{~g} / \mathrm{dl}$ and $55 \%$ for 2010 report). The variation between centres remained high (32-83\%).

Median $\mathrm{Hb}$ of patients at dialysis start by modality was also examined (data not shown). Median $\mathrm{Hb}$ at dialysis start was $9.8 \mathrm{~g} / \mathrm{dl}$ [inter-quartile range (IQR) 9.0-10.8 g/dl)] and $11.1 \mathrm{~g} / \mathrm{dl}$ (IQR $10.1-12.0 \mathrm{~g} / \mathrm{dl}$ ) for $\mathrm{HD}$ and PD patients, respectively. When initiating dialysis, $47.0 \%$ of $\mathrm{HD}$ patients had a $\mathrm{Hb} \geqslant 10.0 \mathrm{~g} / \mathrm{dl}$, compared to $78.0 \%$ of PD patients.

The median starting $\mathrm{Hb}$ by centre is shown in figure 8.1 and the percentage starting with a $\mathrm{Hb}$ $\geqslant 10.0 \mathrm{~g} / \mathrm{dl}$ by centre is given in figure 8.2 . The distribution of $\mathrm{Hb}$ in incident dialysis patients during 2010 is shown in figure 8.3.

Incident dialysis patients from 2009 were followed for one year and the median haemoglobin (and percentage with $\mathrm{a} \mathrm{Hb} \geqslant 10.0 \mathrm{~g} / \mathrm{dl}$ ) of survivors at the end of each quarter was calculated (figures 8.4 and 8.5 ). $\mathrm{Hb}$ is higher in those surviving 3 months reflecting both the treatment administered and poor survival of sicker, more anaemic patients.

The annual distribution of $\mathrm{Hb}$ in incident dialysis patients is shown in figure 8.6. Since 2006 the proportion

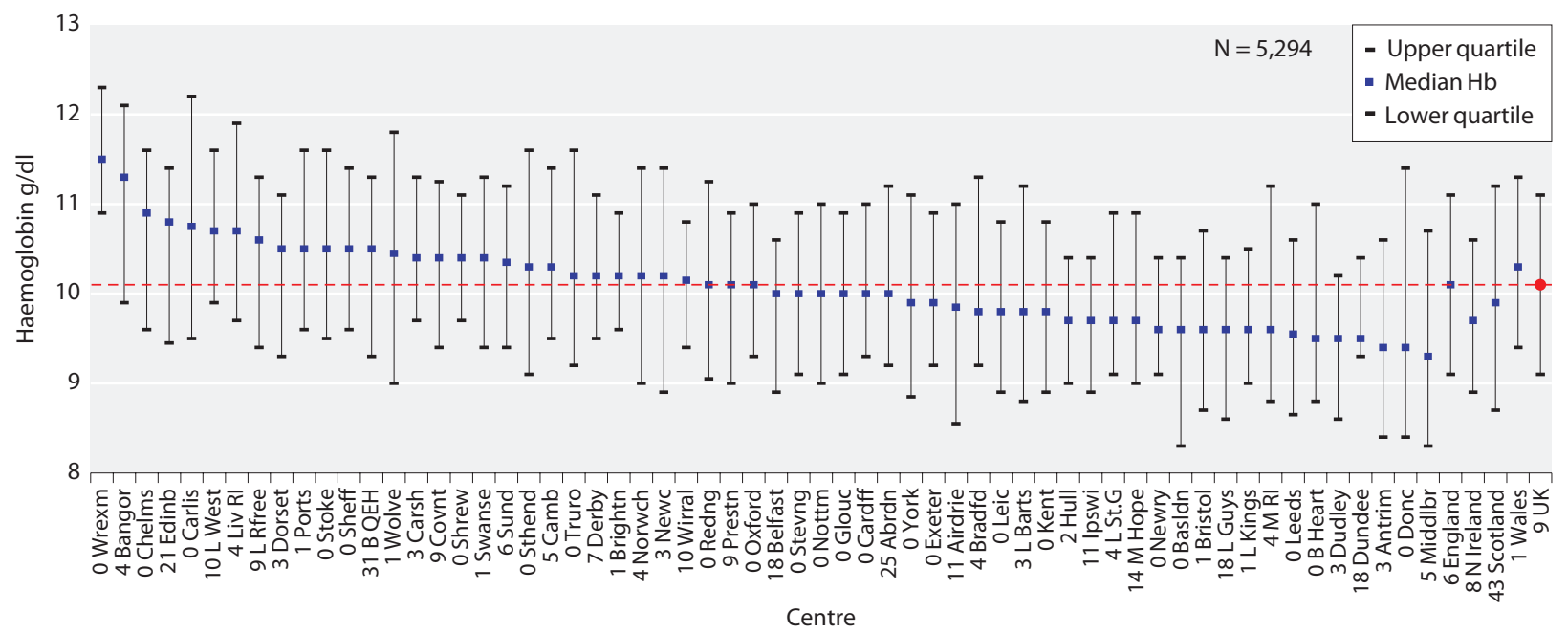

Fig. 8.1. Median haemoglobin for incident dialysis patients at start of dialysis treatment in 2010 


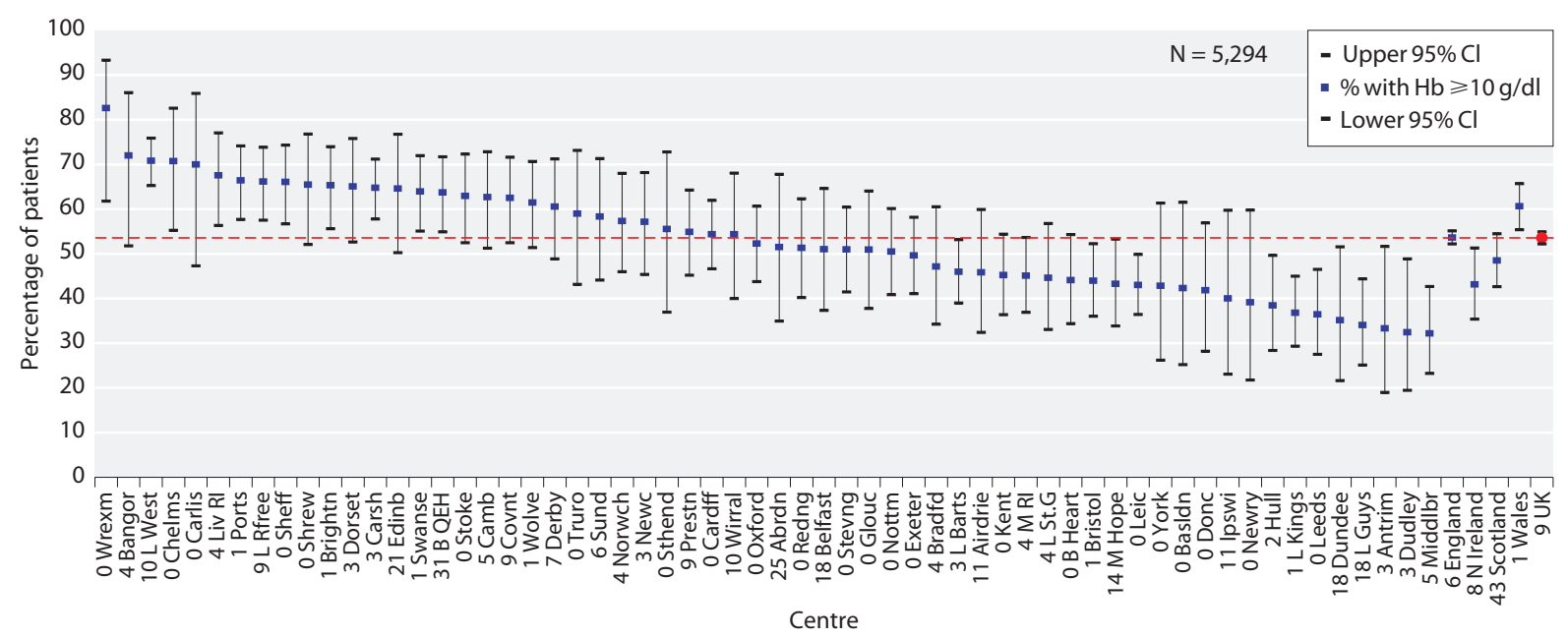

Fig. 8.2. Percentage of incident dialysis patients with $\mathrm{Hb} \geqslant 10 \mathrm{~g} / \mathrm{dl}$ at start of dialysis treatment in 2010

of incident patients with $\mathrm{Hb} \geqslant 12 \mathrm{~g} / \mathrm{dl}$ has fallen from $17.2 \%$ to $11.5 \%$.

\section{Haemoglobin in prevalent haemodialysis patients}

Compliance with data returns and $\mathrm{Hb}$ outcome for prevalent HD patients in the $72 \mathrm{UK}$ renal centres are shown in table 8.2.

The median $\mathrm{Hb}$ of patients on $\mathrm{HD}$ in the UK was $11.5 \mathrm{~g} / \mathrm{dl}$ with an IQR of $10.5-12.3 \mathrm{~g} / \mathrm{dl}$. In the UK, $85 \%$ of $\mathrm{HD}$ patients had a $\mathrm{Hb} \geqslant 10.0 \mathrm{~g} / \mathrm{dl}$. These UK averages are very similar to the values published in the last few UKRR reports. The median $\mathrm{Hb}$ by centre, compliance with the previous UK minimum standard of $\mathrm{Hb} \geqslant 10.0 \mathrm{~g} / \mathrm{dl}$ and EBPG standard of $\mathrm{Hb}$ $\geqslant 11.0 \mathrm{~g} / \mathrm{dl}$ are shown in figures $8.7,8.8$ and 8.9 respectively. The distribution of $\mathrm{Hb}$ in $\mathrm{HD}$ patients by centre is shown in figure 8.10. The compliance with the new RA Clinical Practice Guidelines [7] recommended range of $10.0-12.0 \mathrm{~g} / \mathrm{dl}$ is shown in figure 8.11 . In $2010,52.7 \%$ of prevalent $\mathrm{HD}$ patients had a $\mathrm{Hb}$ within this target range. The majority of centres complied well with respect to both the minimum and target range $\mathrm{Hb}$ standards but it was possible to fall within $2-3 \mathrm{SDs}$ of the mean in the funnel plot (figure 8.12) for a percentage of patients with $\mathrm{Hb} \geqslant 10$ and $\leqslant 12 \mathrm{~g} / \mathrm{dl}$ and yet have a poor compliance with percentage of $\mathrm{Hb} \geqslant 10.0 \mathrm{~g} / \mathrm{dl}$ (figure 8.13). This demonstrates that compliance with one standard $(\mathrm{Hb}$ $\geqslant 10$ and $\leqslant 12 \mathrm{~g} / \mathrm{dl}$ ) can be achieved without compliance with another standard $(\mathrm{Hb} \geqslant 10.0 \mathrm{~g} / \mathrm{dl})$. Table $8.2 \mathrm{can}$ be used in conjunction with figures 8.12 and 8.13 to identify centres.

\section{Haemoglobin in prevalent peritoneal dialysis patients}

In the UK $87 \%$ of patients on $\mathrm{PD}$ had a $\mathrm{Hb} \geqslant 10.0 \mathrm{~g} / \mathrm{dl}$ (table 8.3). The median $\mathrm{Hb}$ of patients on $\mathrm{PD}$ in the UK was $11.6 \mathrm{~g} / \mathrm{dl}$ with an IQR of 10.6-12.5 g/dl. These UK averages are very similar to the values published in the last few UKRR reports. The median $\mathrm{Hb}$ by centre, compliance with the UK minimum standard $\mathrm{Hb} \geqslant 10.0 \mathrm{~g} / \mathrm{dl}$ and EBPG $\mathrm{Hb} \geqslant 11.0 \mathrm{~g} / \mathrm{dl}$ are shown in figures 8.14, 8.15 and 8.16 respectively. The compliance with RA and NICE $[5,6]$ recommended range $\mathrm{Hb} \geqslant 10.5$ and $\leqslant 12.5 \mathrm{~g} / \mathrm{dl}$ is shown in figure 8.17 . In $2010,54.3 \%$ of prevalent $\mathrm{PD}$ patients had a $\mathrm{Hb}$ within the target range. The distribution of $\mathrm{Hb}$ in $\mathrm{PD}$ patients by centre is shown in figure 8.18. The funnel plot for percentage $\mathrm{Hb} \geqslant 10.0 \mathrm{~g} / \mathrm{dl}$ is shown in figure 8.19 . Table 8.3 can be used to identify centres in the funnel plot.

\section{Relationship between $\mathrm{Hb}$ in incident and prevalent dialysis patients in 2010}

The relationship between the percentage of new and prevalent dialysis ( $\mathrm{HD}$ and $\mathrm{PD}$ ) patients with a $\mathrm{Hb}$ $\geqslant 10.0 \mathrm{~g} / \mathrm{dl}$ is shown in figure 8.20. As expected, all centres have a higher percentage of prevalent patients achieving a $\mathrm{Hb} \geqslant 10.0 \mathrm{~g} / \mathrm{dl}$ than incident patients. Overall in the UK, $85.0 \%$ of prevalent patients, compared to $53.6 \%$ of incident patients, had a $\mathrm{Hb} \geqslant 10.0 \mathrm{~g} / \mathrm{dl}$ in 2010 .

\section{Correlation between median haemoglobin and compliance with clinical guidelines}

Rose-Day plots (figures 8.21 to 8.24 ) are used to 


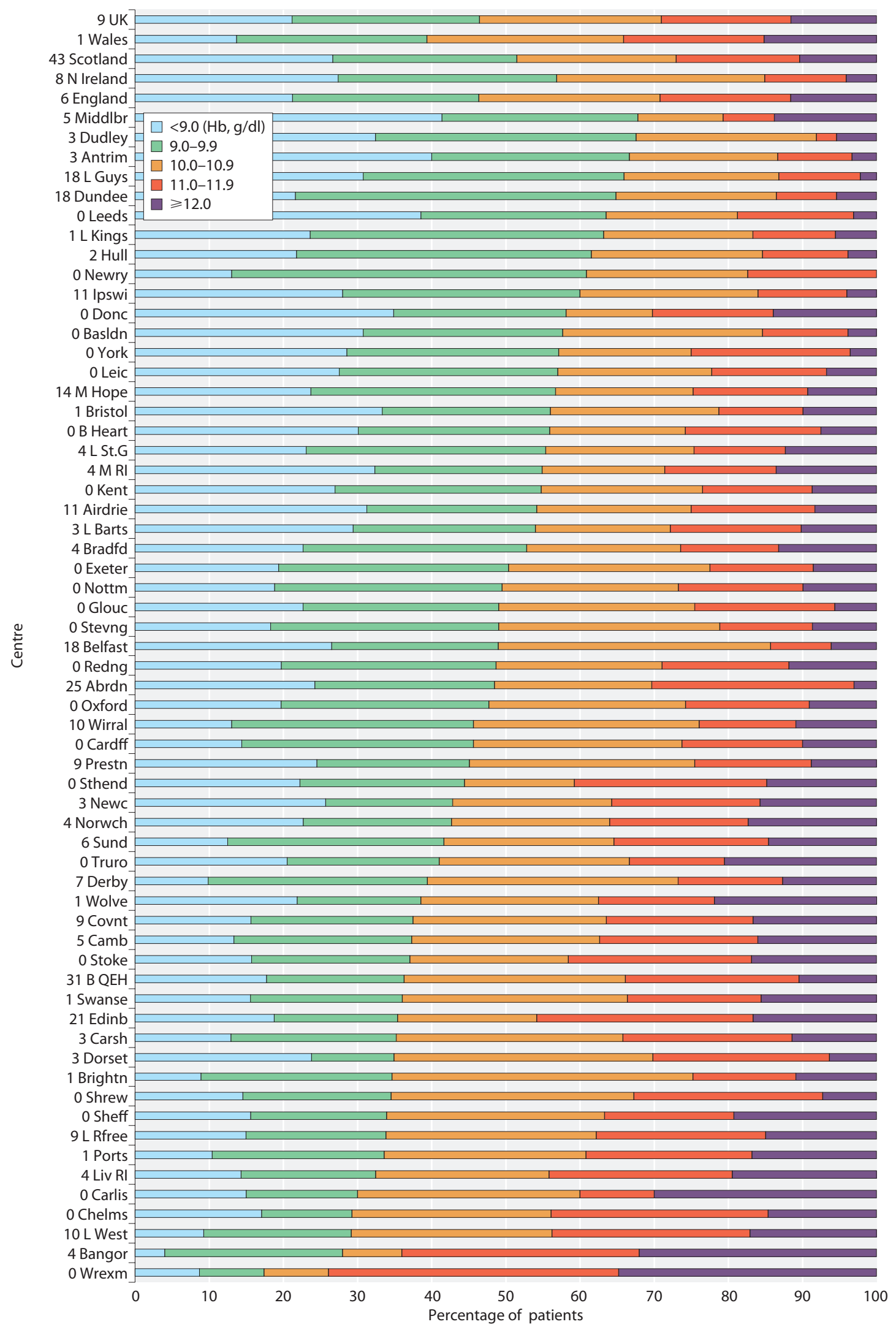

Fig. 8.3. Distribution of haemoglobin in incident dialysis patients at start of dialysis treatment in 2010 


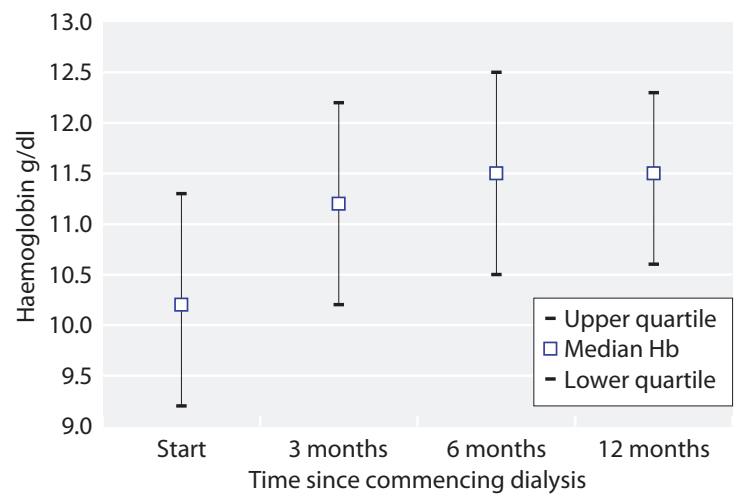

Fig. 8.4. Median haemoglobin, by time on dialysis, for incident dialysis patients in 2009

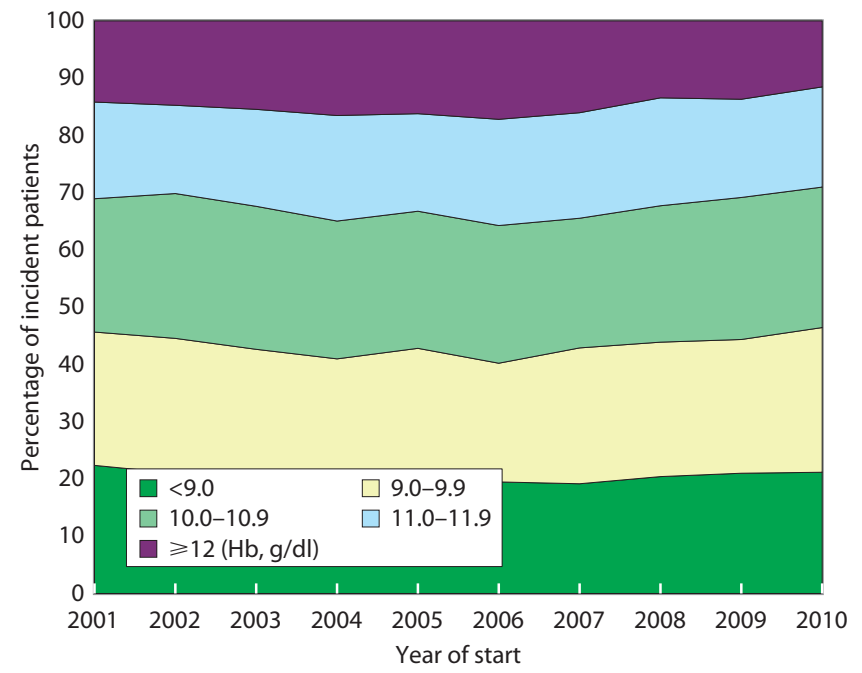

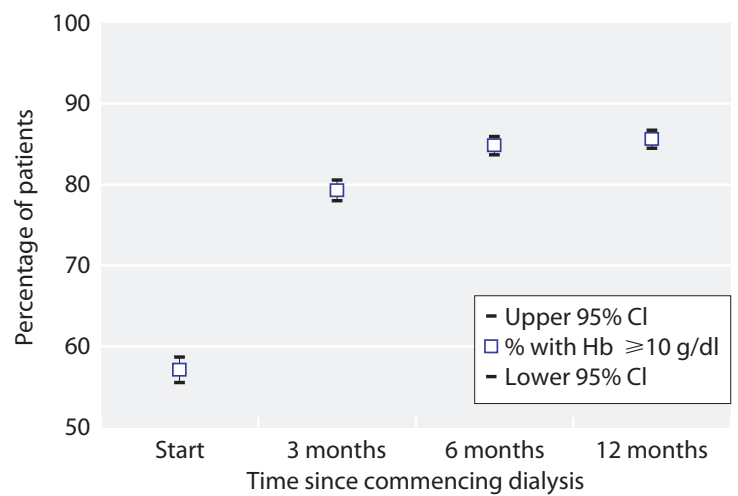

Fig. 8.5. Percentage of incident dialysis patients in 2009 with $\mathrm{Hb}$ $\geqslant 10 \mathrm{~g} / \mathrm{dl}$, by time on dialysis

Fig. 8.6. Distribution of haemoglobin in incident dialysis patients by year of start

Table 8.2. Haemoglobin data for prevalent HD patients in 2010

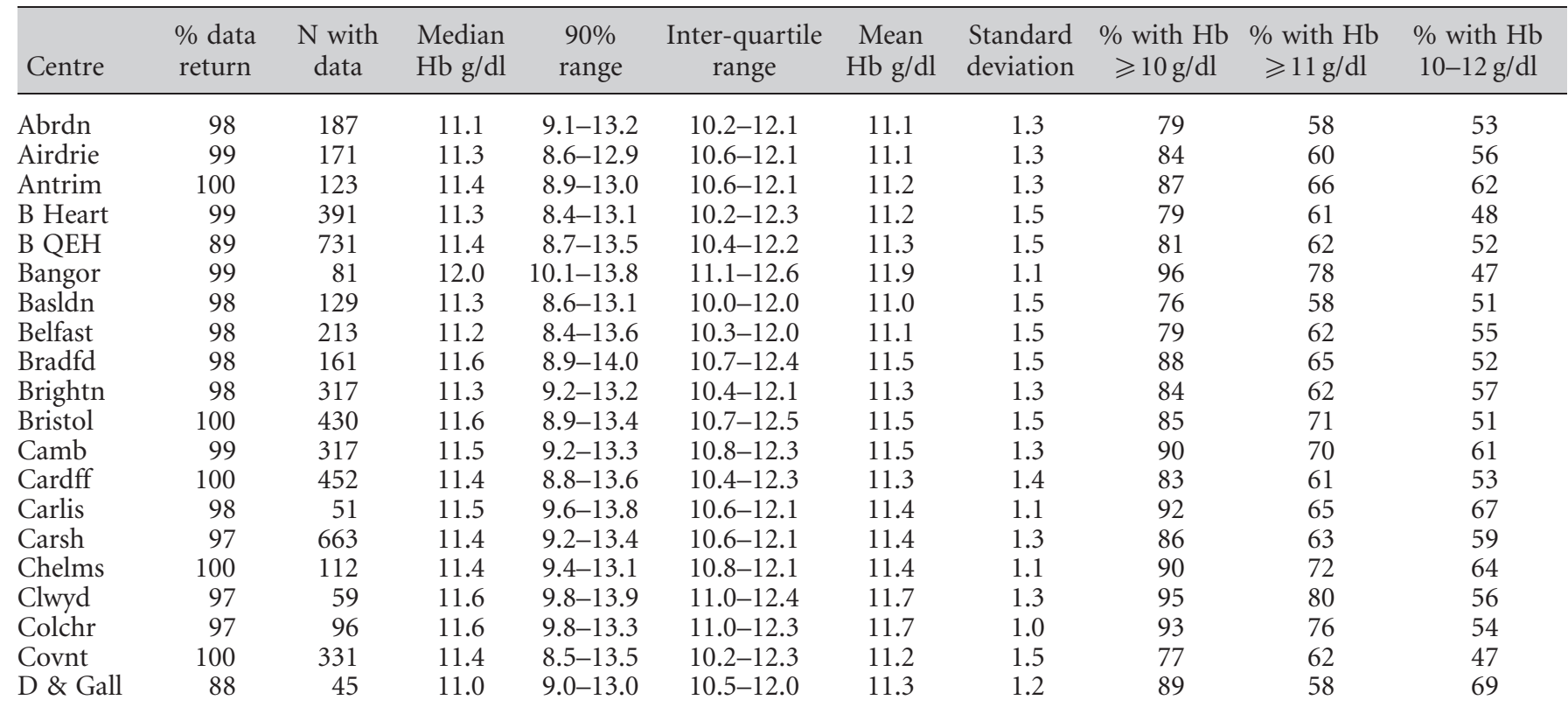


Table 8.2. Continued

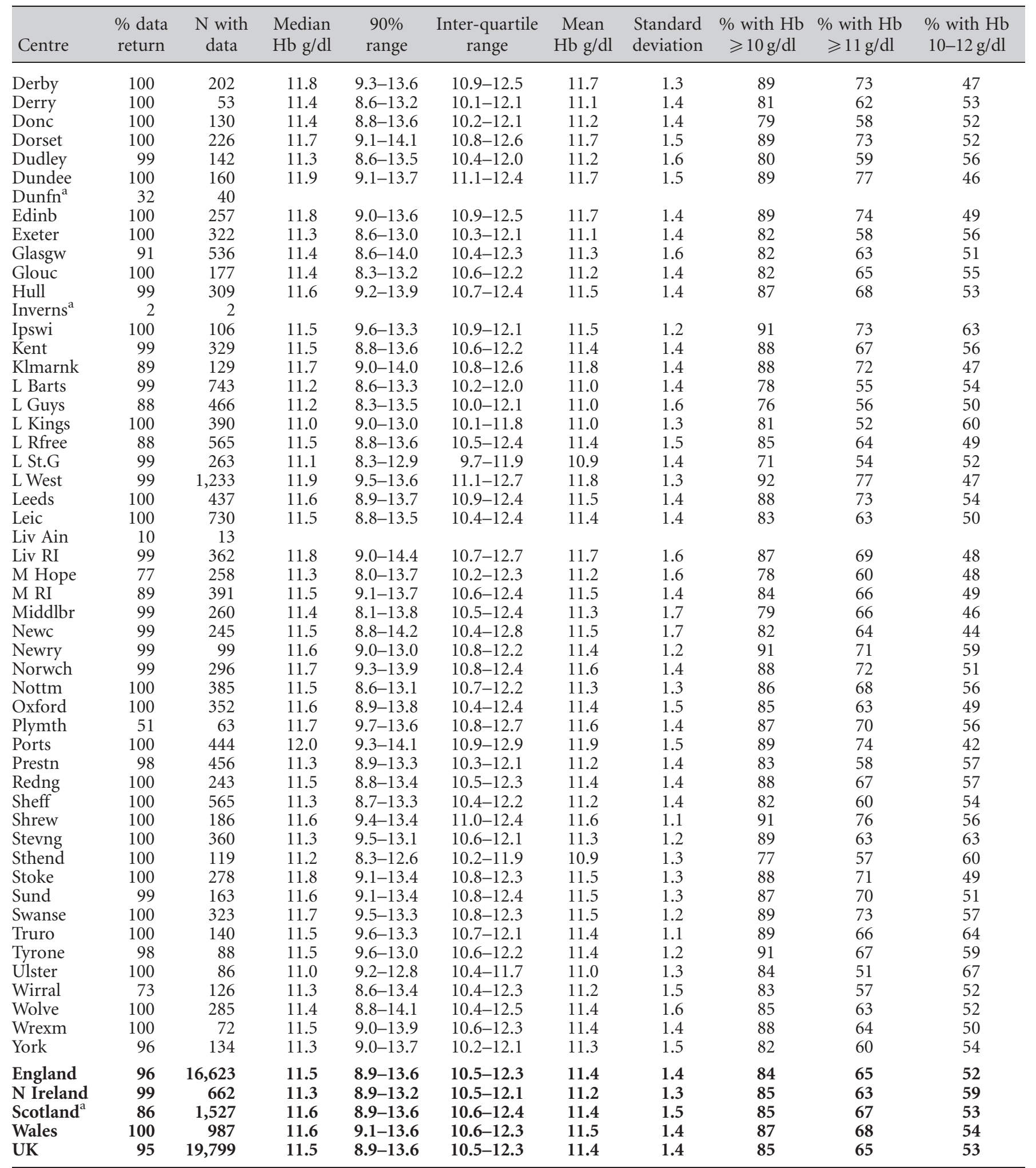

Blank cells = centres excluded from analyses due to poor data completeness or low patient numbers

${ }^{a}$ A data extraction problem resulted in the UKRR not collecting all available data for these centres. The Scottish Renal Registry (www.srr.scot.nhs.uk <http://www.srr.scot.nhs.uk/>) record data completeness $>90 \%$ for both centres and also for Scotland as a whole 


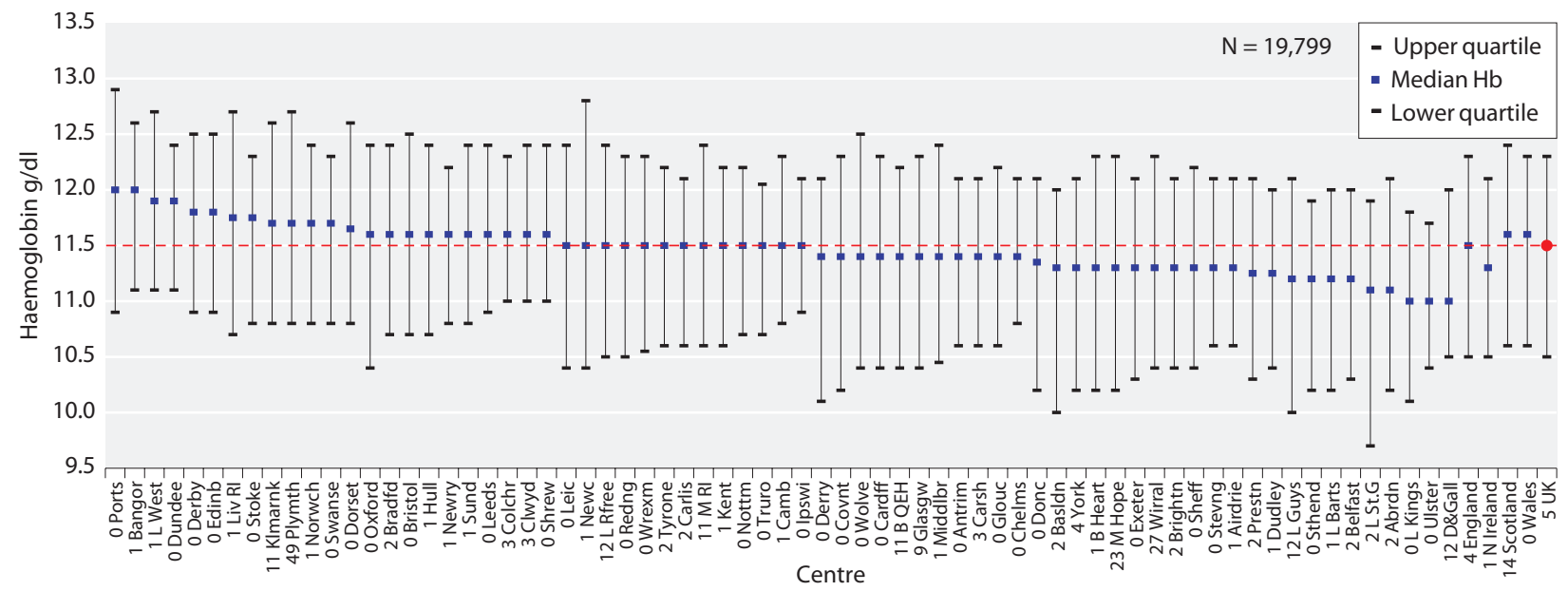

Fig. 8.7. Median haemoglobin in patients treated with HD by centre in 2010

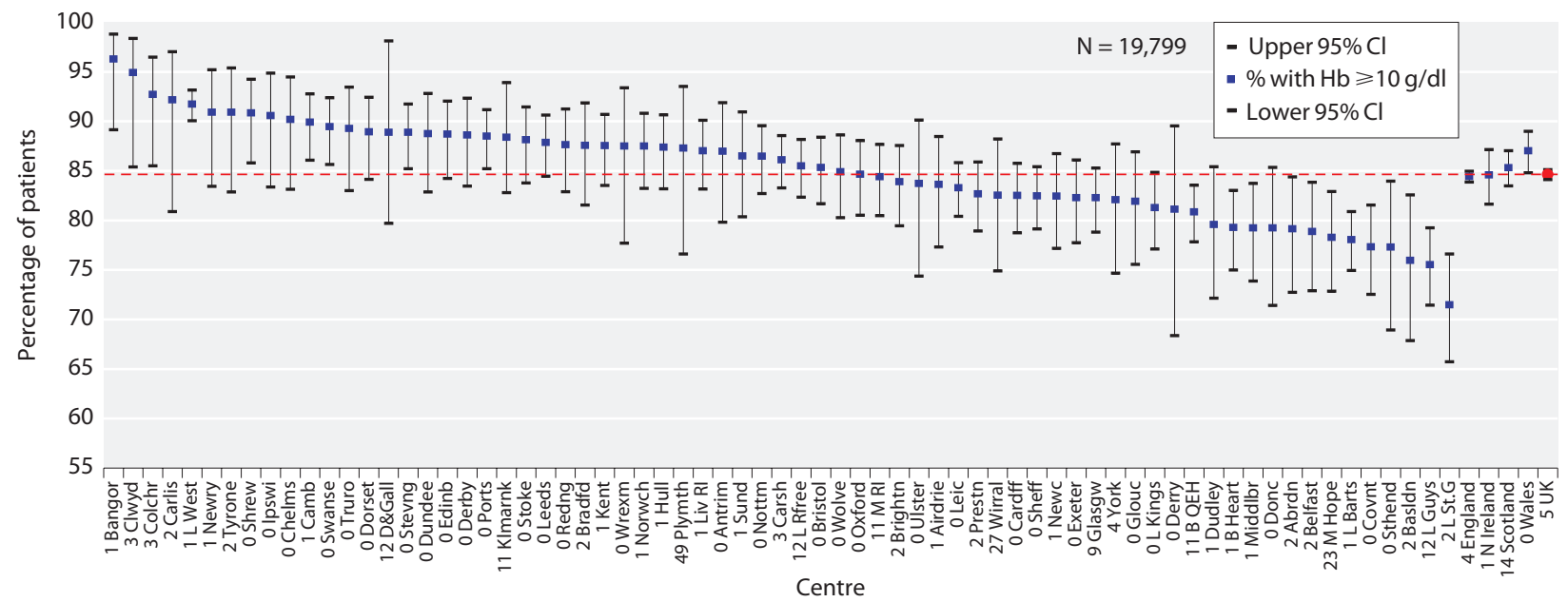

Fig. 8.8. Percentage of HD patients with $\mathrm{Hb} \geqslant 10 \mathrm{~g} / \mathrm{dl}$ by centre in 2010

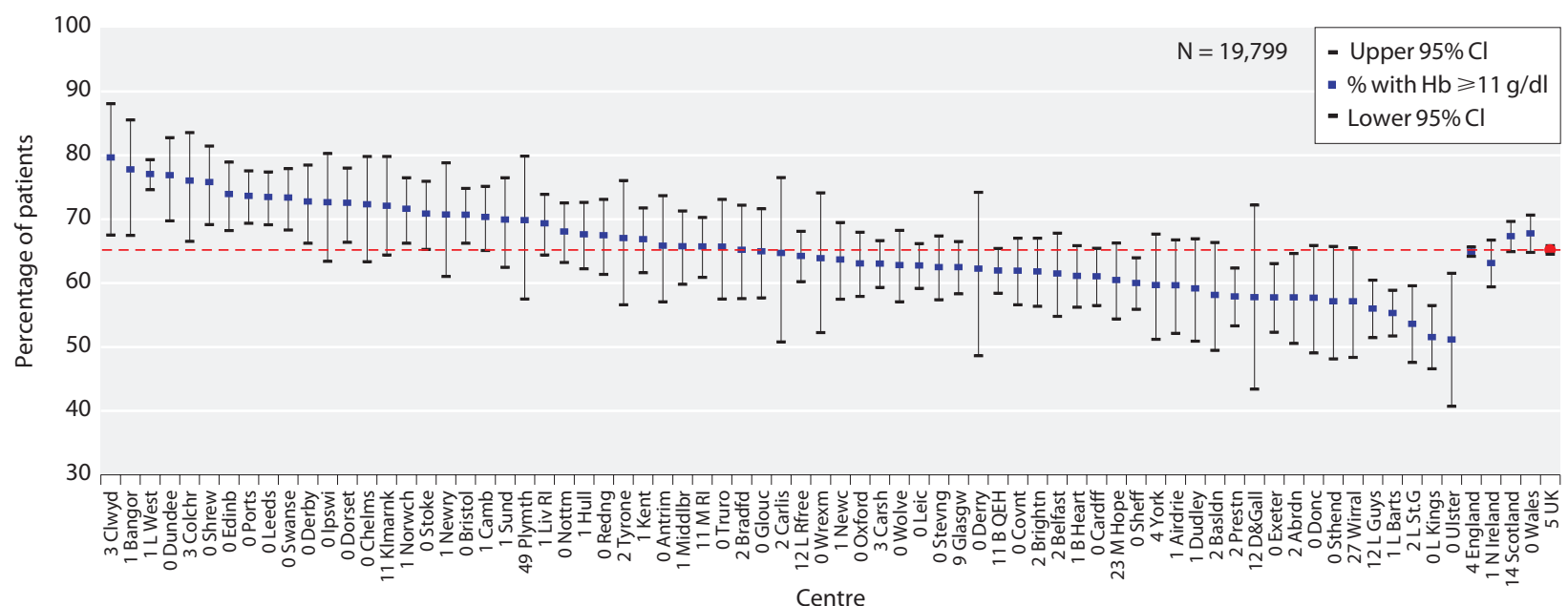

Fig. 8.9. Percentage of HD patients with $\mathrm{Hb} \geqslant 11 \mathrm{~g} / \mathrm{dl}$ by centre in 2010 


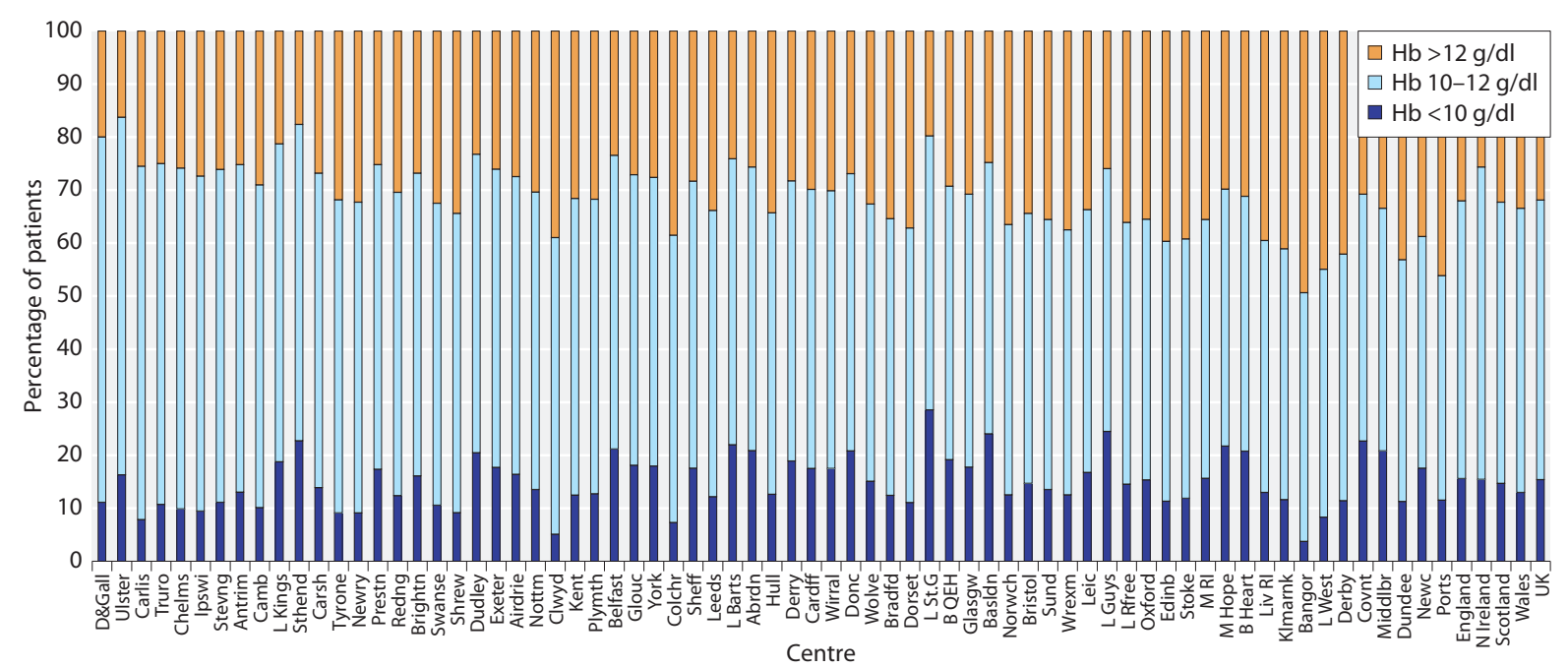

Fig. 8.10. Distribution of haemoglobin in patients treated with HD by centre in 2010

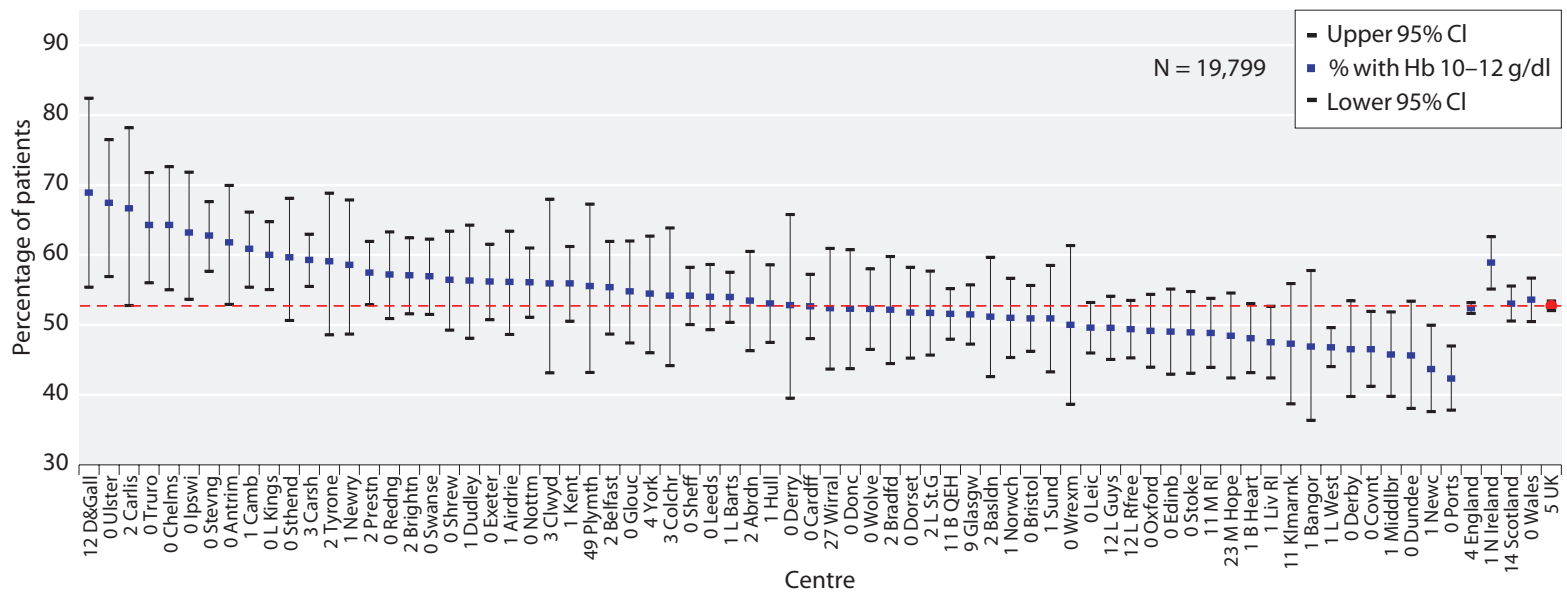

Fig. 8.11. Percentage of $\mathrm{HD}$ patients with $\mathrm{Hb} \geqslant 10$ and $\leqslant 12 \mathrm{~g} / \mathrm{dl}$ by centre in 2010

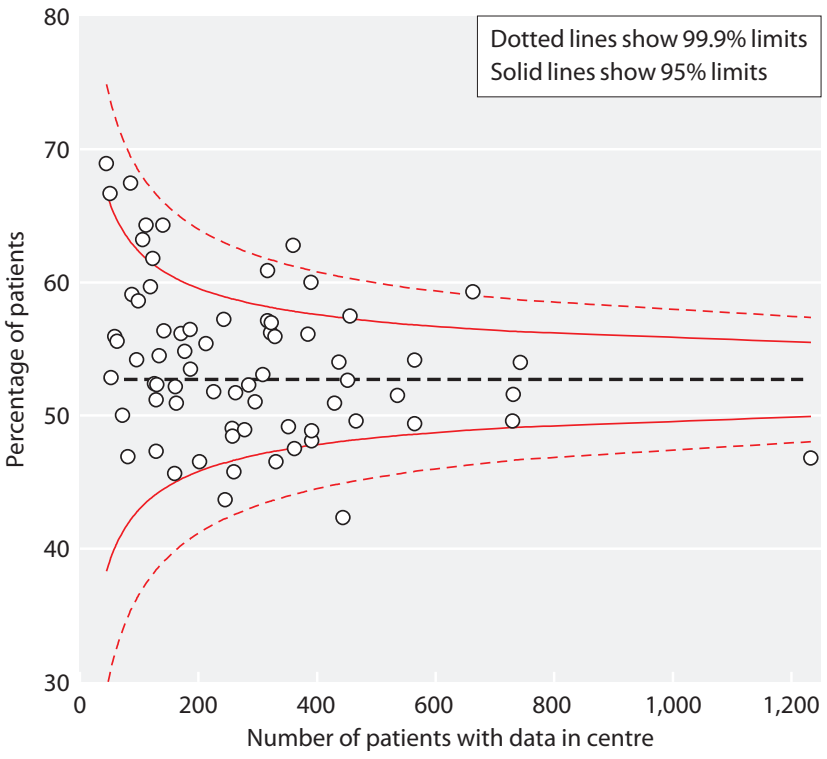

Anaemia Management in UK Dialysis Patients
Fig. 8.12. Funnel plot of percentage of $\mathrm{HD}$ patients with $\mathrm{Hb} \geqslant 10$ and $\leqslant 12 \mathrm{~g} /$ dl by centre in 2010

Nephron Clin Pract 2012;120(suppl 1):c145-c174 


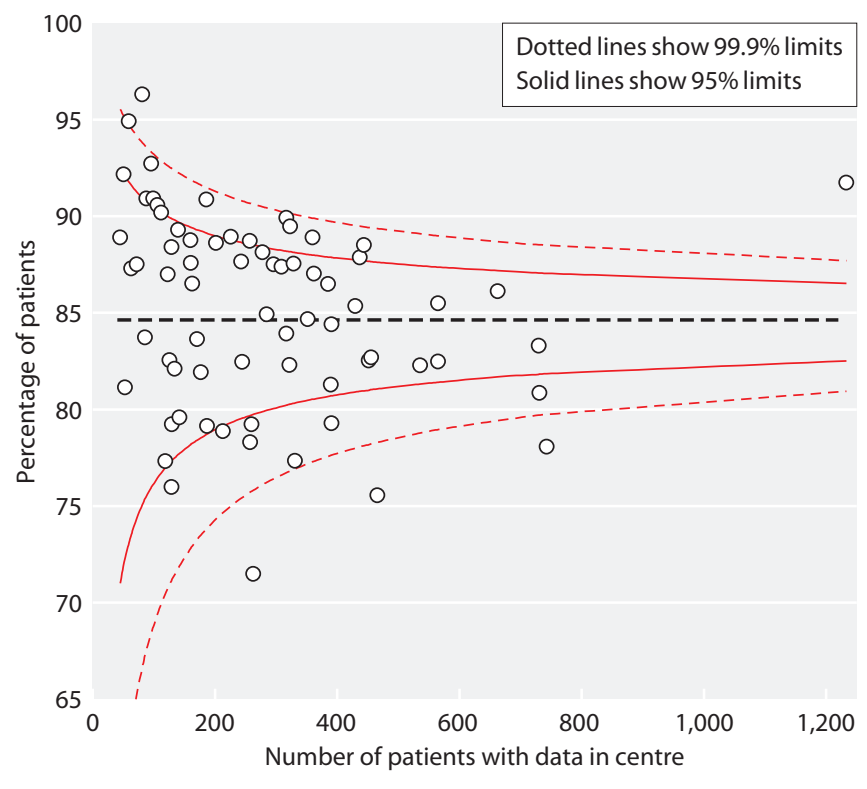

Fig. 8.13. Funnel plot of percentage of $\mathrm{HD}$ patients with $\mathrm{Hb}$ $\geqslant 10 \mathrm{~g} / \mathrm{dl}$ by centre in 2010

Table 8.3. Haemoglobin data for prevalent PD patients in 2010

\begin{tabular}{|c|c|c|c|c|c|c|c|c|c|c|}
\hline Centre & $\begin{array}{l}\% \text { data } \\
\text { return }\end{array}$ & $\begin{array}{l}\text { N with } \\
\text { data }\end{array}$ & $\begin{array}{l}\text { Median } \\
\mathrm{Hb} \text { g/dl }\end{array}$ & $\begin{array}{l}90 \% \\
\text { range }\end{array}$ & $\begin{array}{l}\text { Inter-quartile } \\
\text { range }\end{array}$ & $\begin{array}{c}\text { Mean } \\
\mathrm{Hb} \text { g/dl }\end{array}$ & $\begin{array}{l}\text { Standard } \\
\text { deviation }\end{array}$ & $\begin{array}{c}\% \text { with } \mathrm{Hb} \\
\geqslant 10 \mathrm{~g} / \mathrm{dl}\end{array}$ & $\begin{array}{c}\% \text { with } \mathrm{Hb} \\
\geqslant 11 \mathrm{~g} / \mathrm{dl}\end{array}$ & $\begin{array}{c}\% \text { with } \mathrm{Hb} \\
10.5-12.5 \mathrm{~g} / \mathrm{dl}\end{array}$ \\
\hline Abrdn & 96 & 27 & 11.4 & $9.6-13.0$ & $10.6-12.2$ & 11.5 & 1.1 & 93 & 70 & 67 \\
\hline Antrim & 100 & 11 & & & & & & & & \\
\hline B Heart & 100 & 36 & 11.7 & $8.9-14.4$ & $11.1-12.6$ & 11.7 & 1.5 & 86 & 75 & 58 \\
\hline $\mathrm{B} \mathrm{QEH}$ & 90 & 126 & 11.6 & $9.4-14.0$ & $10.6-12.6$ & 11.6 & 1.5 & 87 & 66 & 51 \\
\hline Belfast & 96 & 24 & 11.6 & $8.9-12.9$ & $10.5-12.1$ & 11.4 & 1.5 & 88 & 67 & 54 \\
\hline Bradfd & 100 & 33 & 10.9 & $7.5-14.4$ & $9.8-12.8$ & 11.2 & 2.0 & 73 & 48 & 33 \\
\hline Brightn & 100 & 75 & 11.8 & $9.7-13.7$ & $11.0-12.5$ & 11.7 & 1.2 & 91 & 76 & 59 \\
\hline Bristol & 100 & 56 & 12.0 & $9.1-14.2$ & $11.3-13.2$ & 12.0 & 1.5 & 88 & 84 & 54 \\
\hline Camb & 100 & 31 & 11.8 & $8.9-14.0$ & $11.2-12.6$ & 11.7 & 1.6 & 87 & 77 & 61 \\
\hline Cardff & 100 & 87 & 11.7 & $9.4-14.0$ & $10.6-12.6$ & 11.6 & 1.5 & 85 & 66 & 51 \\
\hline Colchr & $\mathrm{n} / \mathrm{a}$ & $\mathrm{n} / \mathrm{a}$ & & & & & & & & \\
\hline Covnt & 97 & 70 & 11.1 & $9.2-14.3$ & $10.4-12.6$ & 11.3 & 1.6 & 84 & 54 & 47 \\
\hline D \& Gall & 100 & 6 & & & & & & & & \\
\hline Derby & 99 & 88 & 11.6 & $9.3-14.1$ & $10.7-12.8$ & 11.7 & 1.6 & 88 & 73 & 50 \\
\hline Derry & 100 & 2 & & & & & & & & \\
\hline Donc & 100 & 23 & 11.6 & $8.8-12.9$ & $10.6-12.2$ & 11.4 & 1.4 & 83 & 70 & 65 \\
\hline Dorset & 100 & 51 & 11.9 & $10.0-14.0$ & $11.0-12.7$ & 12.0 & 1.3 & 96 & 80 & 53 \\
\hline Dudley & 97 & 56 & 12.0 & $9.8-13.6$ & $10.9-12.8$ & 11.8 & 1.3 & 91 & 71 & 55 \\
\hline Dundee & 95 & 19 & & & & & & & & \\
\hline Dunfn & 100 & 26 & 12.2 & $9.8-13.6$ & $10.8-12.8$ & 11.9 & 1.7 & 92 & 73 & 54 \\
\hline Edinb & 98 & 47 & 11.2 & $9.6-14.5$ & $10.5-12.2$ & 11.5 & 1.5 & 87 & 62 & 57 \\
\hline Exeter & 100 & 69 & 11.6 & $9.6-13.4$ & $10.8-12.4$ & 11.6 & 1.3 & 90 & 74 & 61 \\
\hline
\end{tabular}


Table 8.3. Continued

\begin{tabular}{|c|c|c|c|c|c|c|c|c|c|c|}
\hline Centre & $\begin{array}{l}\% \text { data } \\
\text { return }\end{array}$ & $\begin{array}{l}\mathrm{N} \text { with } \\
\text { data }\end{array}$ & $\begin{array}{l}\text { Median } \\
\mathrm{Hb} \text { g/dl }\end{array}$ & $\begin{array}{l}90 \% \\
\text { range }\end{array}$ & $\begin{array}{l}\text { Inter-quartile } \\
\text { range }\end{array}$ & $\begin{array}{l}\text { Mean } \\
\mathrm{Hb} \text { g/dl }\end{array}$ & $\begin{array}{l}\text { Standard } \\
\text { deviation }\end{array}$ & $\begin{array}{c}\% \text { with } \mathrm{Hb} \\
\geqslant 10 \mathrm{~g} / \mathrm{dl}\end{array}$ & $\begin{array}{c}\% \text { with } \mathrm{Hb} \\
\geqslant 11 \mathrm{~g} / \mathrm{dl}\end{array}$ & $\begin{array}{l}\% \text { with } \mathrm{Hb} \\
10.5-12.5 \mathrm{~g} / \mathrm{dl}\end{array}$ \\
\hline Hull & 100 & 62 & 11.4 & $9.2-14.0$ & $10.6-12.5$ & 11.6 & 1.7 & 89 & 65 & 53 \\
\hline Inverns & 0 & 0 & & & & & & & & \\
\hline Ipswi & 97 & 34 & 11.1 & $8.8-14.9$ & $10.6-12.5$ & 11.5 & 1.7 & 88 & 59 & 53 \\
\hline Kent & 100 & 67 & 11.7 & $8.7-13.5$ & $10.5-12.4$ & 11.4 & 1.5 & 85 & 69 & 58 \\
\hline Klmarnk & 80 & 32 & 11.7 & $10.0-14.0$ & $10.8-12.2$ & 11.7 & 1.1 & 97 & 75 & 66 \\
\hline L Barts & 98 & 169 & 11.5 & $8.7-14.2$ & $10.5-12.8$ & 11.6 & 1.6 & 86 & 65 & 49 \\
\hline L Guys & 98 & 42 & 11.1 & $9.1-13.3$ & $10.0-11.7$ & 11.1 & 1.3 & 79 & 52 & 57 \\
\hline L Kings & 100 & 84 & 11.5 & $9.6-13.4$ & $10.7-12.3$ & 11.4 & 1.5 & 86 & 69 & 61 \\
\hline L Rfree & 98 & 62 & 11.4 & $9.7-13.7$ & $10.6-12.3$ & 11.5 & 1.4 & 89 & 65 & 58 \\
\hline L St.G & 98 & 53 & 11.5 & $8.3-13.5$ & $10.6-12.2$ & 11.4 & 1.6 & 83 & 64 & 64 \\
\hline L West & 100 & 31 & 11.2 & $9.4-12.4$ & $10.3-11.8$ & 11.1 & 0.9 & 87 & 58 & 71 \\
\hline Leeds & 99 & 83 & 11.3 & $9.5-13.1$ & $10.5-12.3$ & 11.4 & 1.3 & 88 & 61 & 60 \\
\hline Leic & 99 & 140 & 11.5 & $8.6-13.9$ & $10.3-12.2$ & 11.3 & 1.6 & 84 & 59 & 54 \\
\hline Liv Ain & 0 & 0 & & & & & & & & \\
\hline Liv RI & 99 & 77 & 11.7 & $8.9-14.2$ & $11.0-12.8$ & 11.8 & 1.4 & 91 & 77 & 53 \\
\hline M Hope & 73 & 80 & 11.3 & $8.7-13.6$ & $10.3-12.3$ & 11.3 & 1.5 & 79 & 63 & 49 \\
\hline M RI & 100 & 75 & 11.6 & $8.7-14.4$ & $10.6-12.6$ & 11.5 & 1.7 & 85 & 65 & 55 \\
\hline Middlbr & 94 & 17 & & & & & & & & \\
\hline Newc & 100 & 45 & 11.3 & $8.3-12.8$ & $10.3-12.1$ & 11.1 & 1.5 & 78 & 60 & 60 \\
\hline Newry & 100 & 8 & & & & & & & & \\
\hline Norwch & 100 & 46 & 12.3 & $9.9-14.9$ & $11.1-13.1$ & 12.3 & 1.6 & 93 & 78 & 46 \\
\hline Nottm & 100 & 78 & 11.6 & $9.0-13.5$ & $10.5-12.2$ & 11.4 & 1.3 & 85 & 65 & 62 \\
\hline Oxford & 100 & 101 & 11.6 & $9.3-13.8$ & $10.8-12.6$ & 11.6 & 1.5 & 91 & 71 & 54 \\
\hline Plymth & 84 & 36 & 12.2 & $9.6-14.5$ & $11.3-13.5$ & 12.3 & 1.5 & 94 & 81 & 50 \\
\hline Ports & 100 & 91 & 12.1 & $8.9-14.1$ & $11.0-12.9$ & 11.9 & 1.5 & 89 & 77 & 49 \\
\hline Prestn & 100 & 60 & 11.8 & $9.6-14.1$ & $10.9-12.6$ & 11.7 & 1.4 & 90 & 73 & 55 \\
\hline Redng & 99 & 77 & 11.5 & $8.6-14.1$ & $10.9-12.0$ & 11.5 & 1.5 & 92 & 70 & 66 \\
\hline Sheff & 100 & 60 & 11.6 & $9.2-14.1$ & $10.5-12.6$ & 11.6 & 1.5 & 87 & 67 & 52 \\
\hline Shrew & 94 & 17 & & & & & & & & \\
\hline Stevng & 100 & 28 & 11.4 & $7.4-13.8$ & $9.7-12.9$ & 11.1 & 1.9 & 71 & 64 & 39 \\
\hline Sthend & 100 & 18 & & & & & & & & \\
\hline Stoke & 100 & 65 & 11.7 & $9.6-14.1$ & $10.7-12.9$ & 11.9 & 1.5 & 89 & 71 & 49 \\
\hline Sund & 100 & 29 & 12.0 & $8.9-14.9$ & $10.4-13.2$ & 12.0 & 2.3 & 76 & 66 & 31 \\
\hline Swanse & 100 & 45 & 12.2 & $10.2-13.6$ & $11.6-12.7$ & 12.1 & 1.1 & 98 & 89 & 60 \\
\hline Truro & 100 & 26 & 11.8 & $9.4-12.9$ & $10.6-12.3$ & 11.4 & 1.1 & 92 & 69 & 69 \\
\hline Tyrone & 71 & 5 & & & & & & & & \\
\hline Ulster & 100 & 2 & & & & & & & & \\
\hline Wirral & 54 & 19 & & & & & & & & \\
\hline Wolve & 100 & 62 & 11.5 & $9.2-13.8$ & $10.2-12.4$ & 11.5 & 1.5 & 84 & 58 & 47 \\
\hline Wrexm & 95 & 19 & & & & & & & & \\
\hline York & 100 & 17 & & & & & & & & \\
\hline England & 97 & 2,859 & 11.6 & $9.0-14.1$ & $10.6-12.5$ & 11.6 & 1.5 & 87 & 67 & 54 \\
\hline $\mathrm{N}$ Ireland & 95 & 52 & 11.8 & $9.0-14.7$ & $11.0-12.4$ & 11.7 & 1.4 & 92 & 79 & 62 \\
\hline Scotland & 84 & 207 & 11.4 & $9.7-14.0$ & $10.6-12.3$ & 11.6 & 1.3 & 91 & 68 & 58 \\
\hline Wales & 99 & 178 & 11.9 & $9.6-14.3$ & $11.1-12.8$ & 12.0 & 1.4 & 92 & 78 & 54 \\
\hline UK & 96 & 3,296 & 11.6 & $9.1-14.1$ & $10.6-12.5$ & 11.6 & 1.5 & 87 & 68 & 54 \\
\hline
\end{tabular}

Blank cells $=$ centres excluded from analyses due to poor data completeness or low patient numbers n/a not applicable 


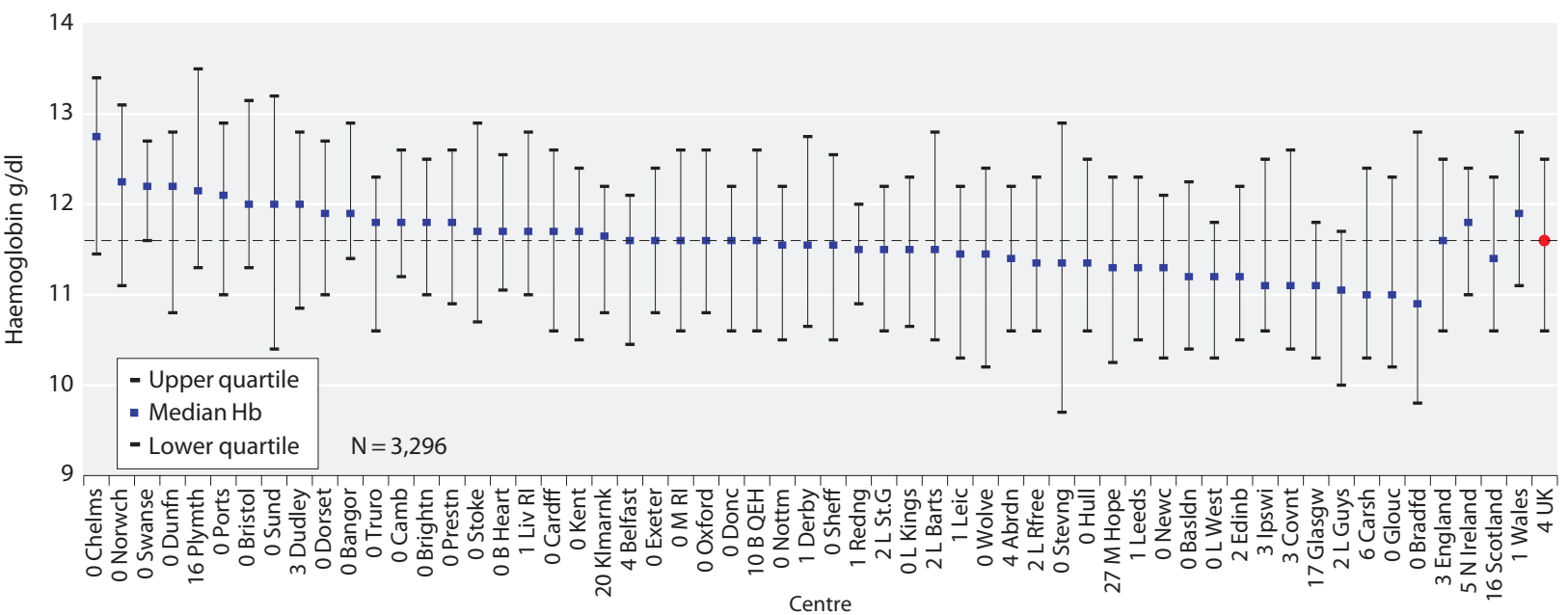

Fig. 8.14. Median haemoglobin in patients treated with PD by centre in 2010

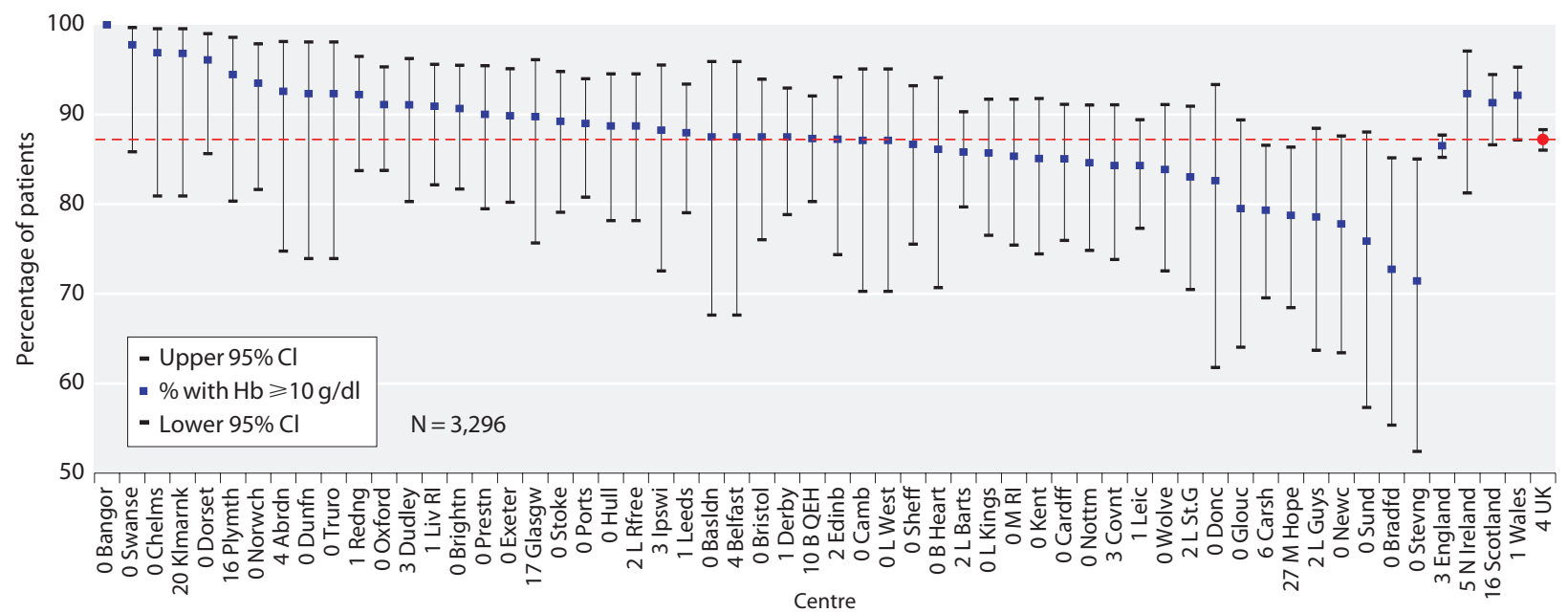

Fig. 8.15. Percentage of $\mathrm{PD}$ patients with $\mathrm{Hb} \geqslant 10 \mathrm{~g} / \mathrm{dl}$ by centre in 2010

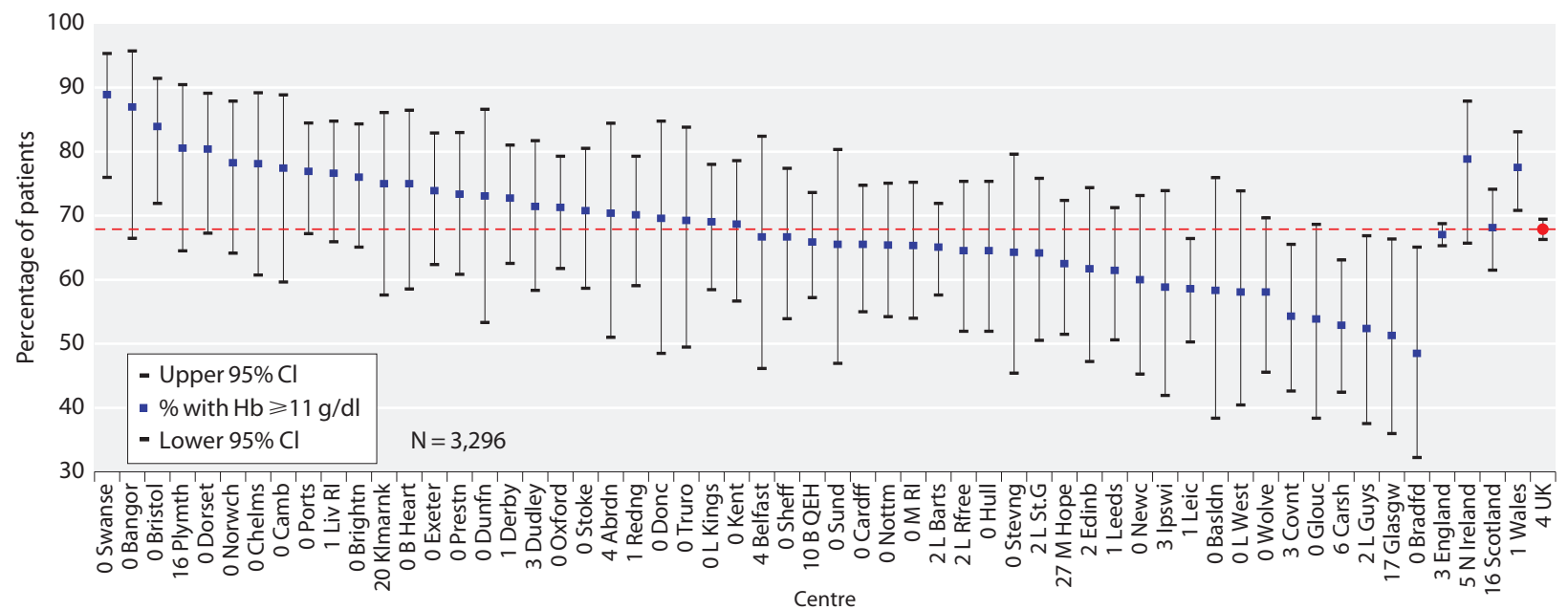

Fig. 8.16. Percentage of $\mathrm{PD}$ patients with $\mathrm{Hb} \geqslant 11 \mathrm{~g} / \mathrm{dl}$ by centre in 2010 


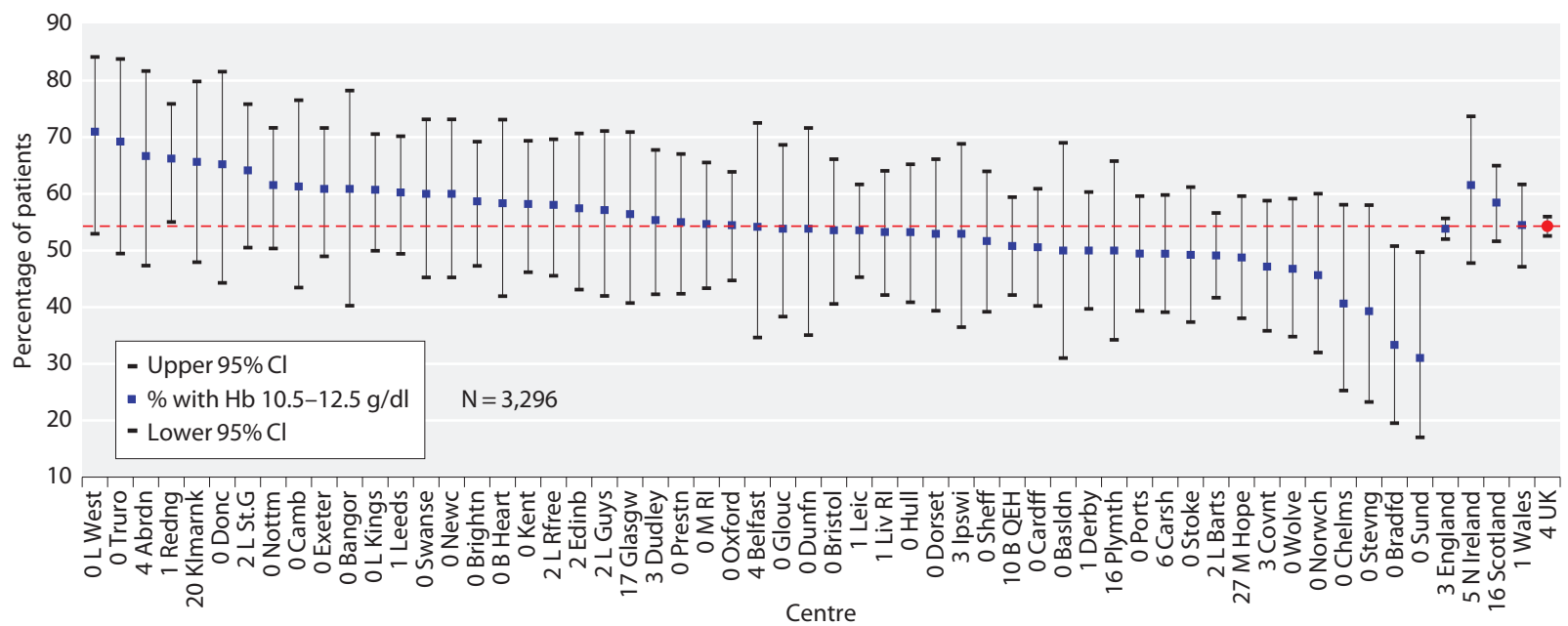

Fig. 8.17. Percentage of PD patients with $\mathrm{Hb} \geqslant 10.5$ and $\leqslant 12.5 \mathrm{~g} / \mathrm{dl}$ by centre in 2010

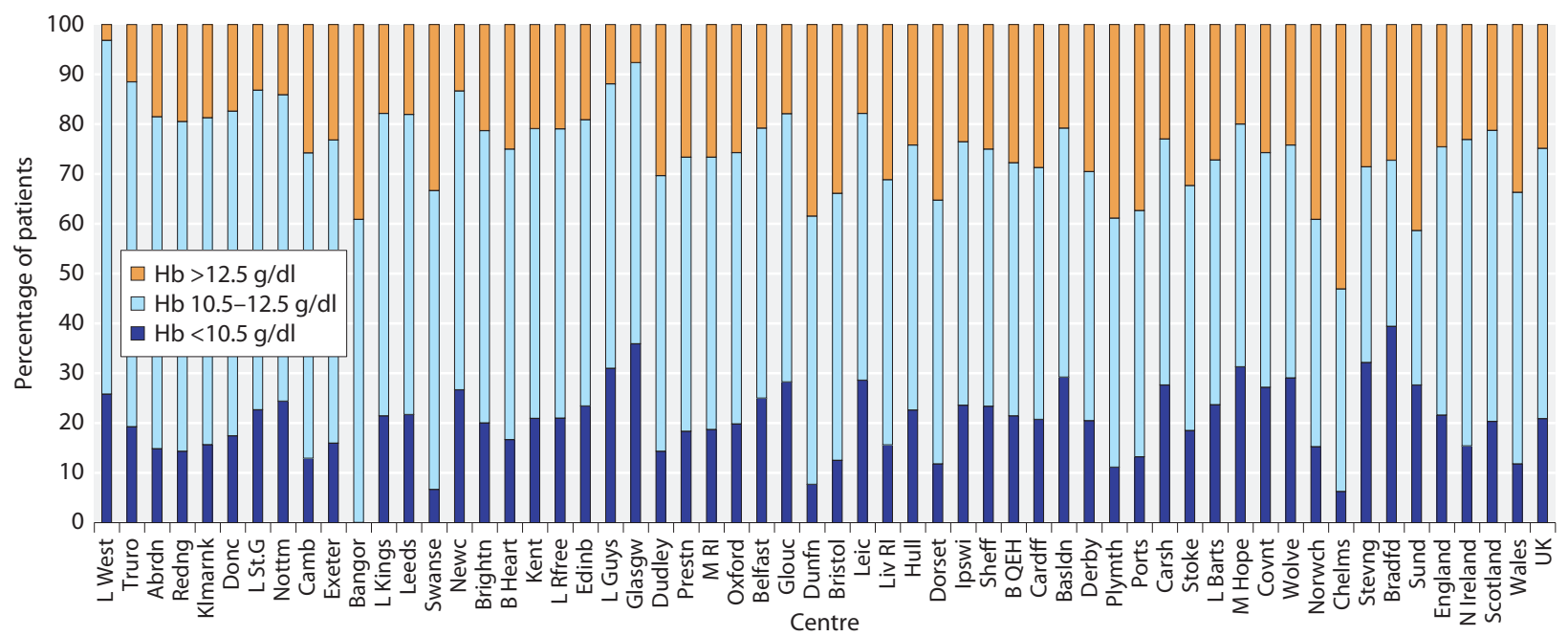

Fig. 8.18. Distribution of haemoglobin in patients treated with PD by centre in 2010

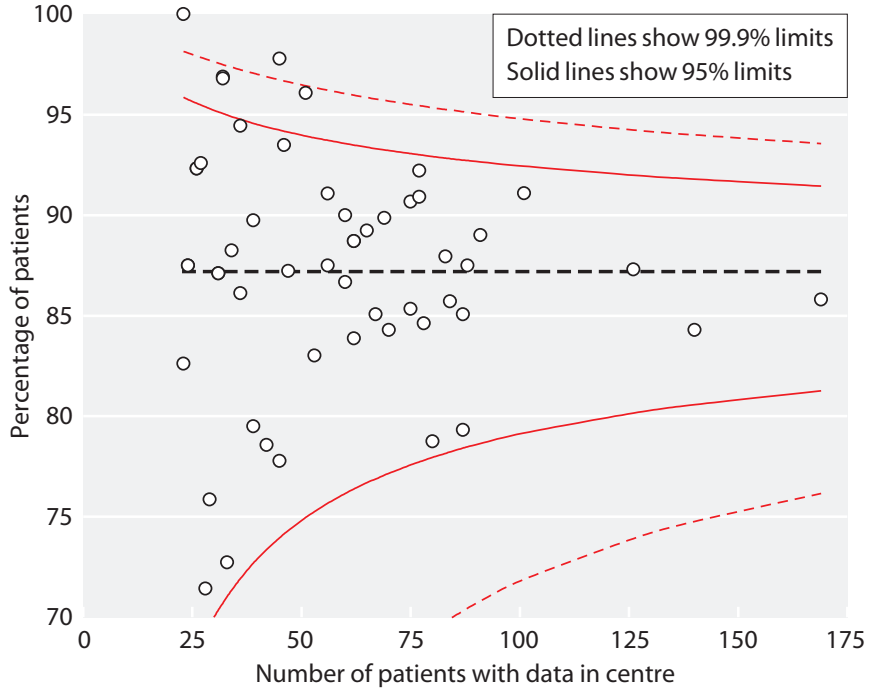

Anaemia Management in UK Dialysis Patients
Fig. 8.19. Funnel plot of percentage of $\mathrm{PD}$ patients with $\mathrm{Hb}$ $\geqslant 10 \mathrm{~g} / \mathrm{dl}$ by centre in 2010 


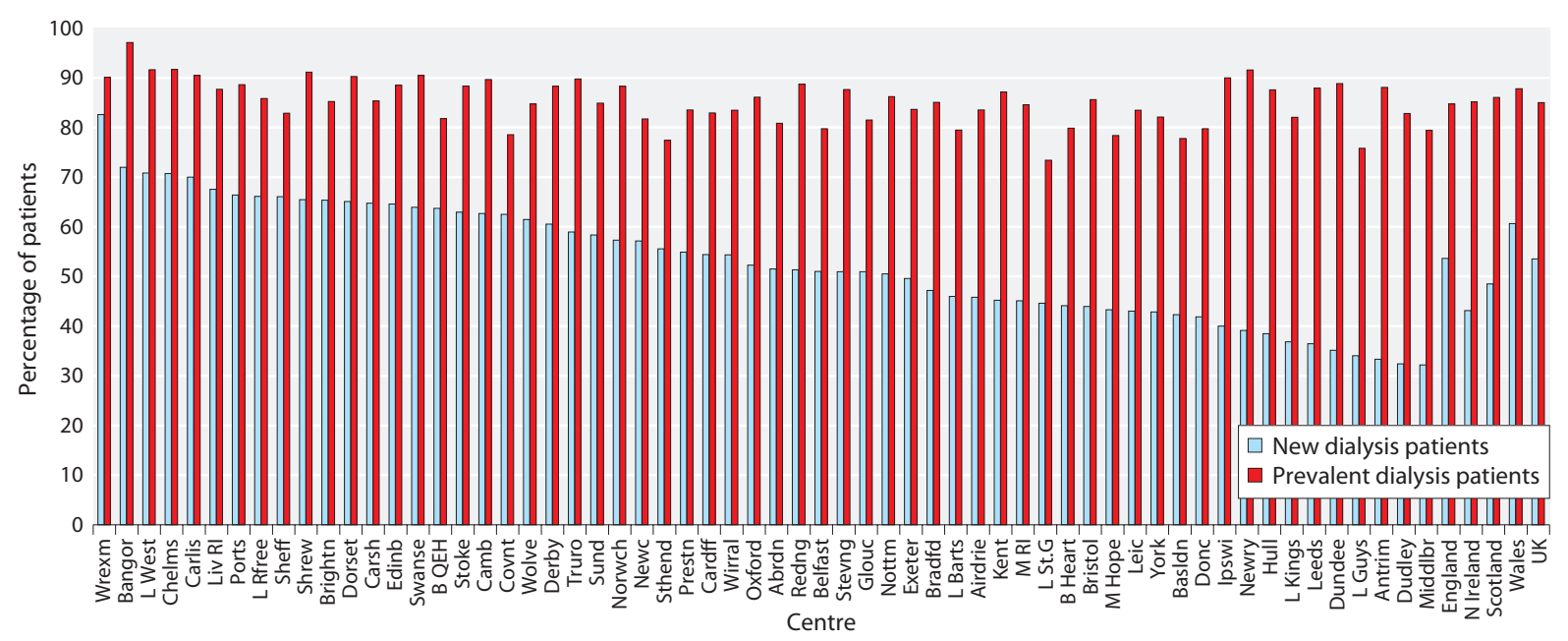

Fig. 8.20. Percentage of new and prevalent dialysis patients with $\mathrm{Hb} \geqslant 10 \mathrm{~g} / \mathrm{dl}$ by centre in 2010

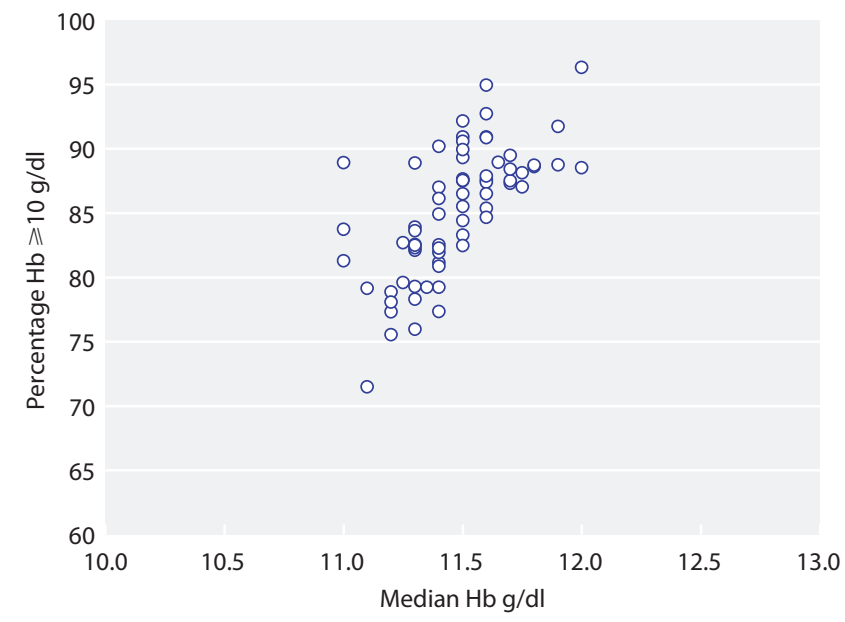

Fig. 8.21. Percentage of $\mathrm{HD}$ patients with $\mathrm{Hb} \geqslant 10 \mathrm{~g} / \mathrm{dl}$ plotted against median haemoglobin by centre in 2010

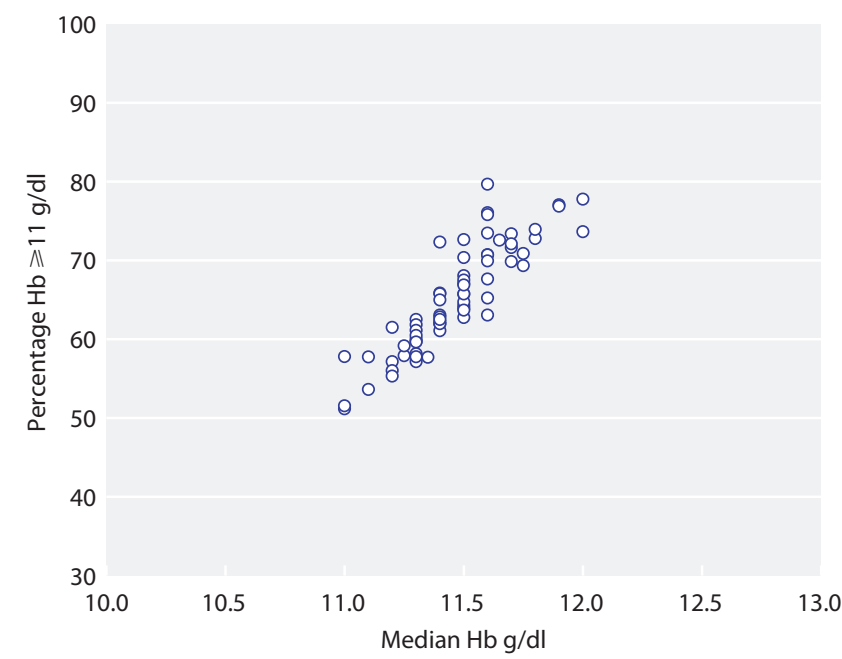

Fig. 8.22. Percentage of $\mathrm{HD}$ patients with $\mathrm{Hb} \geqslant 11 \mathrm{~g} / \mathrm{dl}$ plotted against median haemoglobin by centre in 2010

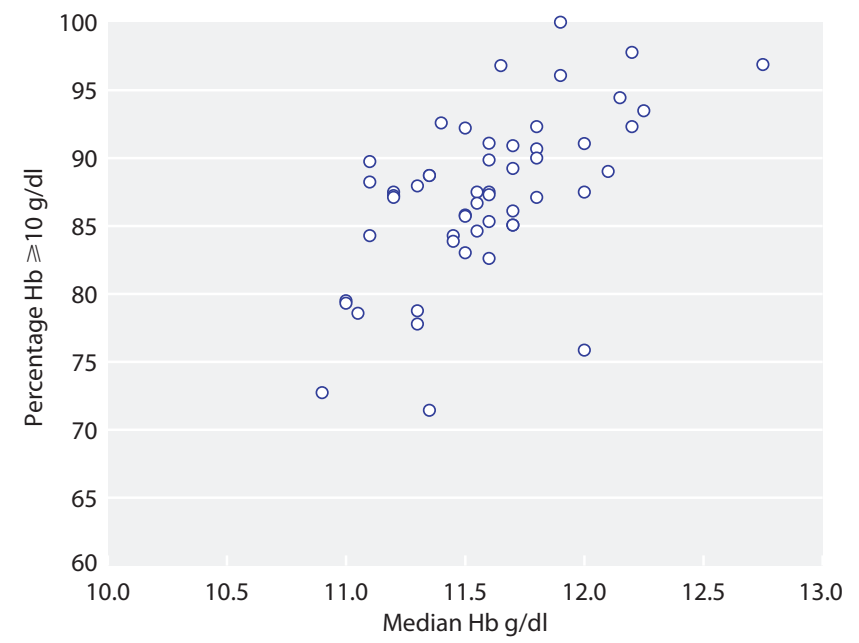

Fig. 8.23. Percentage of $\mathrm{PD}$ patients with $\mathrm{Hb} \geqslant 10 \mathrm{~g} / \mathrm{dl}$ plotted against median haemoglobin by centre in 2010

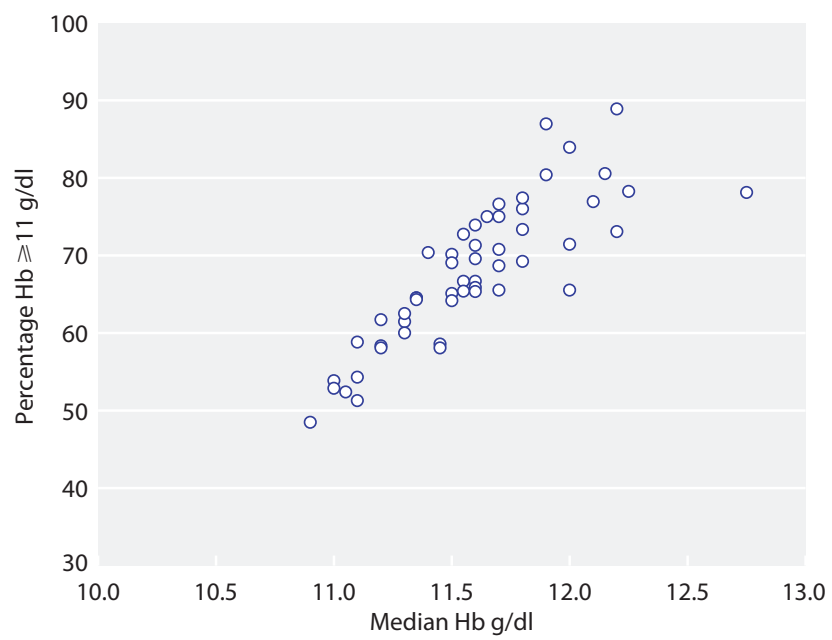

Fig. 8.24. Percentage of $P D$ patients with $H b \geqslant 11 \mathrm{~g} / \mathrm{dl}$ plotted against median haemoglobin by centre in 2010 


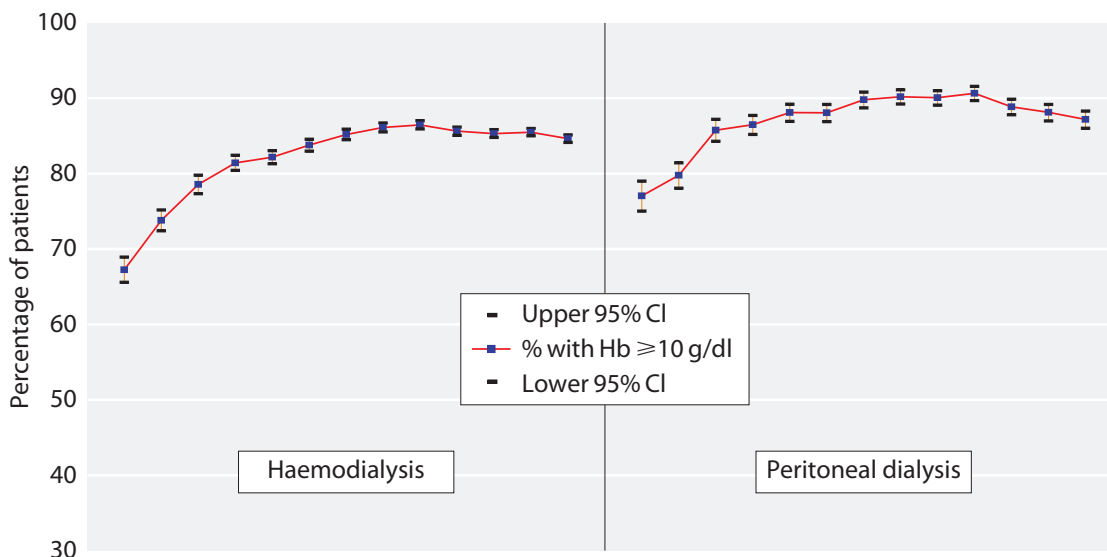

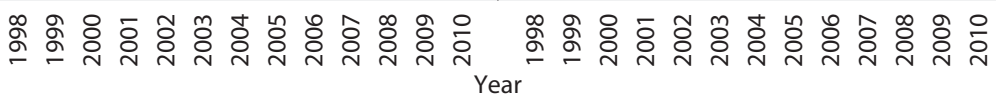

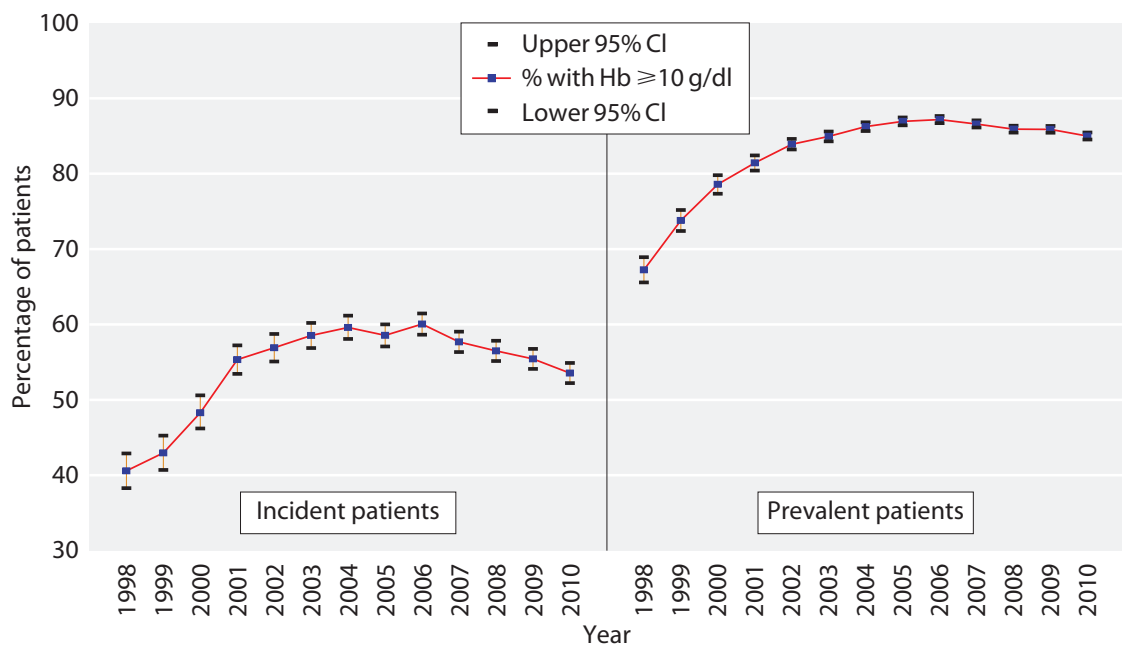

Fig. 8.25. Percentage of prevalent HD and $\mathrm{PD}$ patients (1998-2010) with $\mathrm{Hb}$ $\geqslant 10 \mathrm{~g} / \mathrm{dl}$
Fig. 8.26. Percentage of incident and prevalent dialysis patients (1998-2010) with $\mathrm{Hb} \geqslant 10 \mathrm{~g} / \mathrm{dl}$ show the relationship between a centre's median $\mathrm{Hb}$ and their compliance with minimum standards for $\mathrm{Hb} \geqslant 10.0 \mathrm{~g} / \mathrm{dl}$ and $\geqslant 11.0 \mathrm{~g} / \mathrm{dl}$ in HD and PD populations. Compliance with minimum standards by year (1998 to 2010) is shown in figure 8.25 for prevalent patients (by treatment modality) and in figure 8.26 for incident and prevalent patients (all dialysis patients).

\section{Median haemoglobin and length of survival on $R R T$}

Median $\mathrm{Hb}$ of cohorts of patients who had survived different lengths of time on RRT were analysed in both $\mathrm{HD}$ and PD patients (figures 8.27 and 8.28).

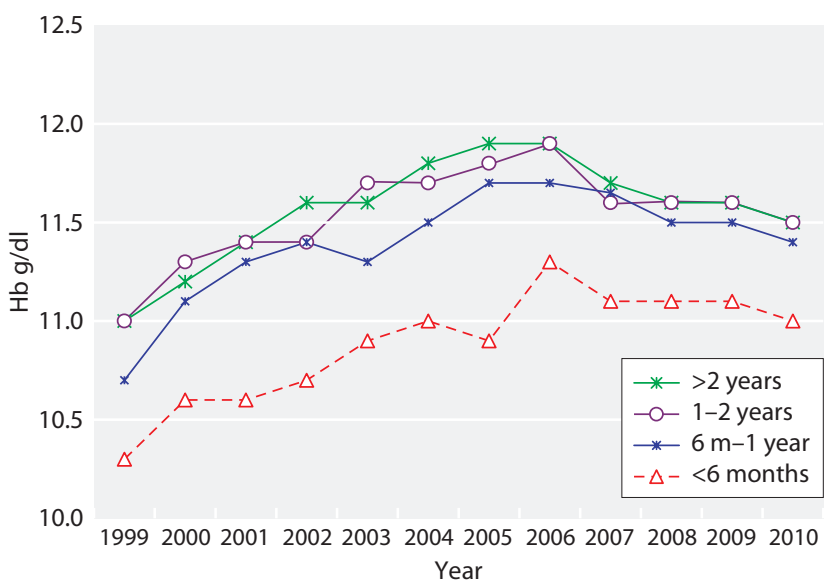

Fig. 8.27. Median haemoglobin plotted by length of time on RRT (HD patients)

Nephron Clin Pract 2012;120(suppl 1):c145-c174 


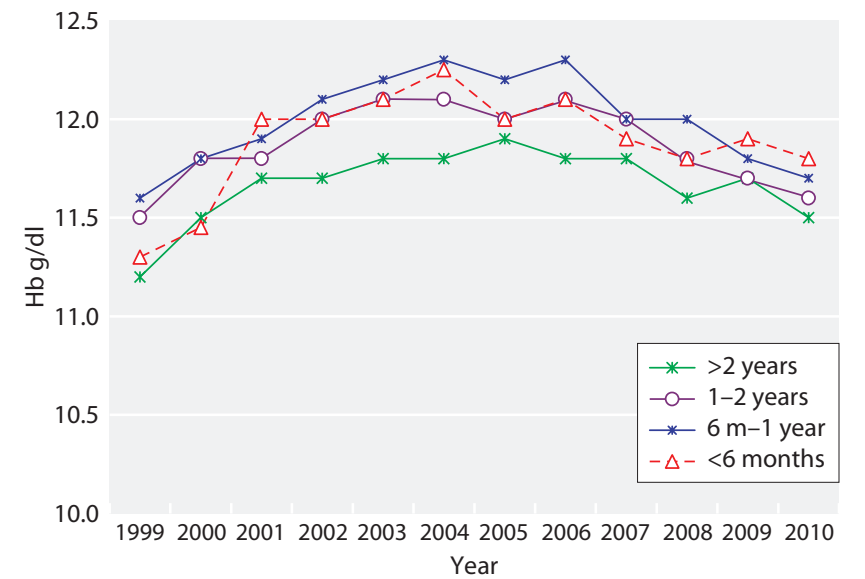

Fig. 8.28. Median haemoglobin plotted by length of time on RRT (PD patients)

\section{Factors affecting haemoglobin}

\section{Ferritin}

Ferritin in prevalent dialysis patients

Percentage returns and summary statistics for serum ferritin are shown for the 63 renal centres in England, Northern Ireland and Wales in tables 8.4 and 8.5 for $\mathrm{HD}$ and PD patients respectively.

The median and IQR for serum ferritin for HD and $\mathrm{PD}$ patients is given, by centre, in figures 8.29 and 8.30 respectively. The percentage of patients with serum ferritin $\geqslant 100 \mu \mathrm{g} / \mathrm{L}, \geqslant 200 \mu \mathrm{g} / \mathrm{L}$ and $\geqslant 800 \mu \mathrm{g} / \mathrm{L}$ are shown in figures $8.31,8.32$ and 8.33 for $\mathrm{HD}$ and figures $8.34,8.35$ and 8.36 for PD respectively.
All centres achieved greater than 90\% compliance with a serum ferritin $\geqslant 100 \mu \mathrm{g} / \mathrm{L}$ for HD patients. The PD population had a lower median ferritin value (264 $\mu \mathrm{g} / \mathrm{L}$, IQR $148-426$ vs. $444 \mu \mathrm{g} / \mathrm{L}$, IQR $299-635$ for HD). In 2010, 31 centres reported less than $90 \%$ of PD patients compliant with serum ferritin $\geqslant 100 \mu \mathrm{g} / \mathrm{L}$.

\section{Changes in ferritin 2001-2010}

The compliance with guidelines for ferritin in the HD populations has been $95 \%$ or above since 2007. In the PD population the compliance has fluctuated over the last few years, and was $85.9 \%$ in 2010 . The serial values are shown in figure 8.37 . The difference between the compliance in HD and PD was probably because more PD patients achieve adequate $\mathrm{Hb}$ without any iron or ESA therapy. The median serum ferritin outcome over time is shown in figure 8.38 .

\section{Ferritin and length of time on renal replacement} therapy

In HD (but not PD) patients, the median serum ferritin was greatest in those who had survived longest (figures 8.39 and 8.40).

\section{Erythropoiesis stimulating agents in prevalent dialysis patients}

Patients treated and dose variation - ESA prescription and modality

Treatment of renal anaemia with ESAs has offered a major way to improve quality of life for dialysis patients. These agents are relatively expensive and thus approaches to achieving normal haemoglobin levels

Table 8.4. Ferritin in HD patients in 2010

\begin{tabular}{|c|c|c|c|c|c|c|c|}
\hline Centre & $\begin{array}{l}\% \text { data } \\
\text { return }\end{array}$ & $\begin{array}{c}\mathrm{N} \text { with } \\
\text { data }\end{array}$ & $\begin{array}{l}\text { Median } \\
\text { ferritin }\end{array}$ & $\begin{array}{l}90 \% \\
\text { range }\end{array}$ & $\begin{array}{l}\text { Inter-quartile } \\
\text { range }\end{array}$ & $\begin{array}{l}\% \text { ferritin } \\
\geqslant 100 \mu \mathrm{g} / \mathrm{L}\end{array}$ & $\begin{array}{l}\% \text { ferritin } \\
\geqslant 800 \mu \mathrm{g} / \mathrm{L}\end{array}$ \\
\hline Antrim & 100 & 123 & 411 & 135-982 & $287-629$ & 98 & 11 \\
\hline B Heart & 95 & 375 & 310 & $65-747$ & $204-446$ & 92 & 2 \\
\hline B QEH & 90 & 738 & 378 & $141-673$ & $303-462$ & 97 & 2 \\
\hline Bangor & 100 & 82 & 553 & 207-961 & $399-716$ & 98 & 11 \\
\hline Basldn & 97 & 128 & 339 & $103-605$ & $270-405$ & 95 & 2 \\
\hline Belfast & 97 & 211 & 534 & $123-1136$ & $326-795$ & 97 & 24 \\
\hline Bradfd & 96 & 158 & 672 & $254-1260$ & $462-878$ & 99 & 32 \\
\hline Brightn & 93 & 300 & 441 & $171-805$ & $305-586$ & 98 & 5 \\
\hline Bristol & 100 & 429 & 604 & $123-1232$ & $431-801$ & 97 & 25 \\
\hline Camb & 72 & 230 & 298 & $96-703$ & $190-411$ & 95 & 4 \\
\hline Cardff & 99 & 448 & 266 & $87-682$ & $171-386$ & 93 & 2 \\
\hline Carlis & 100 & 52 & 498 & $245-2557$ & $391-724$ & 100 & 21 \\
\hline Carsh & 97 & 661 & 350 & $96-784$ & $257-468$ & 95 & 5 \\
\hline Chelms & 98 & 110 & 464 & $239-823$ & $380-561$ & 100 & 7 \\
\hline
\end{tabular}


Table 8.4. Continued

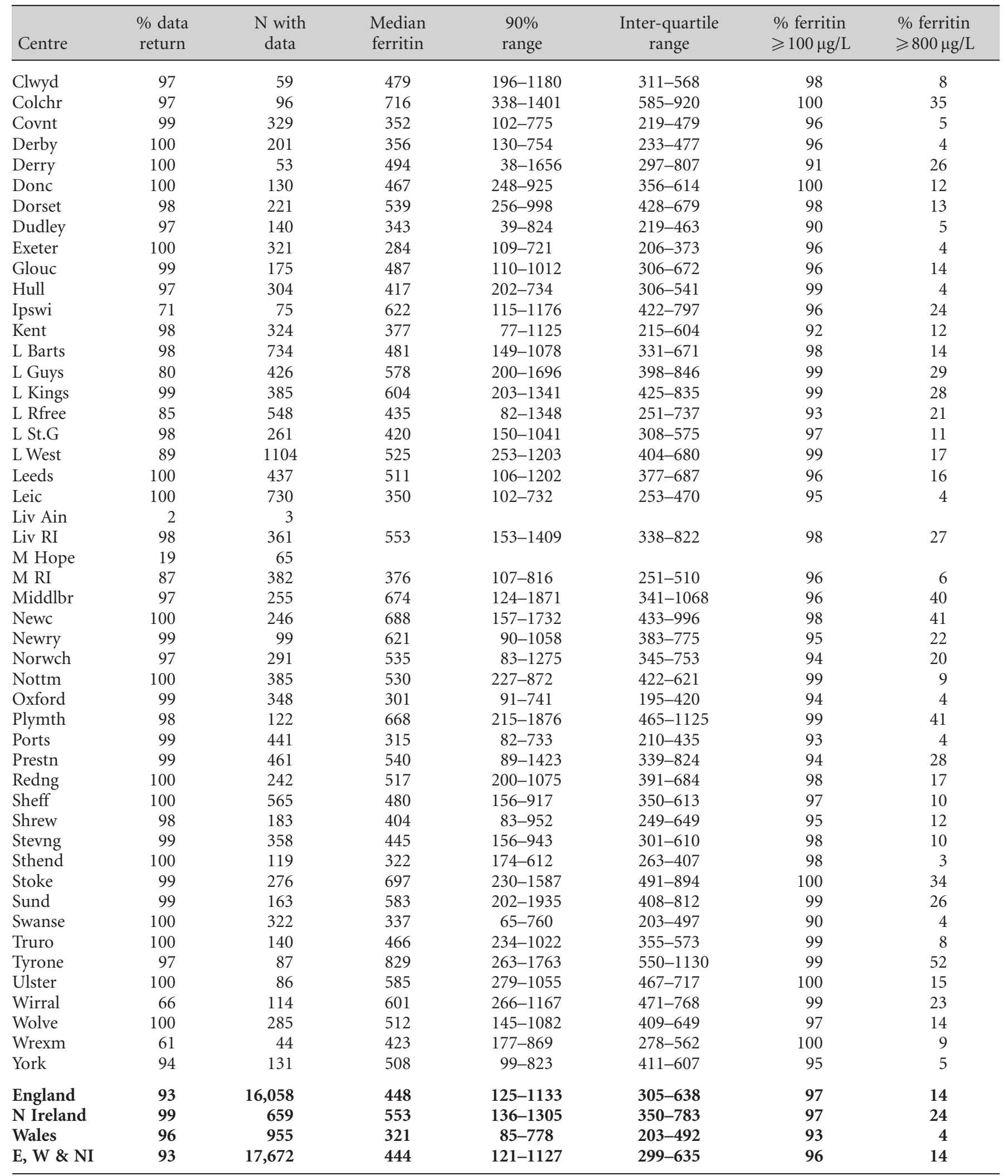

Blank cells $=$ centres excluded from analyses due to poor data completeness or low patient numbers 
Table 8.5. Ferritin in PD patients in 2010

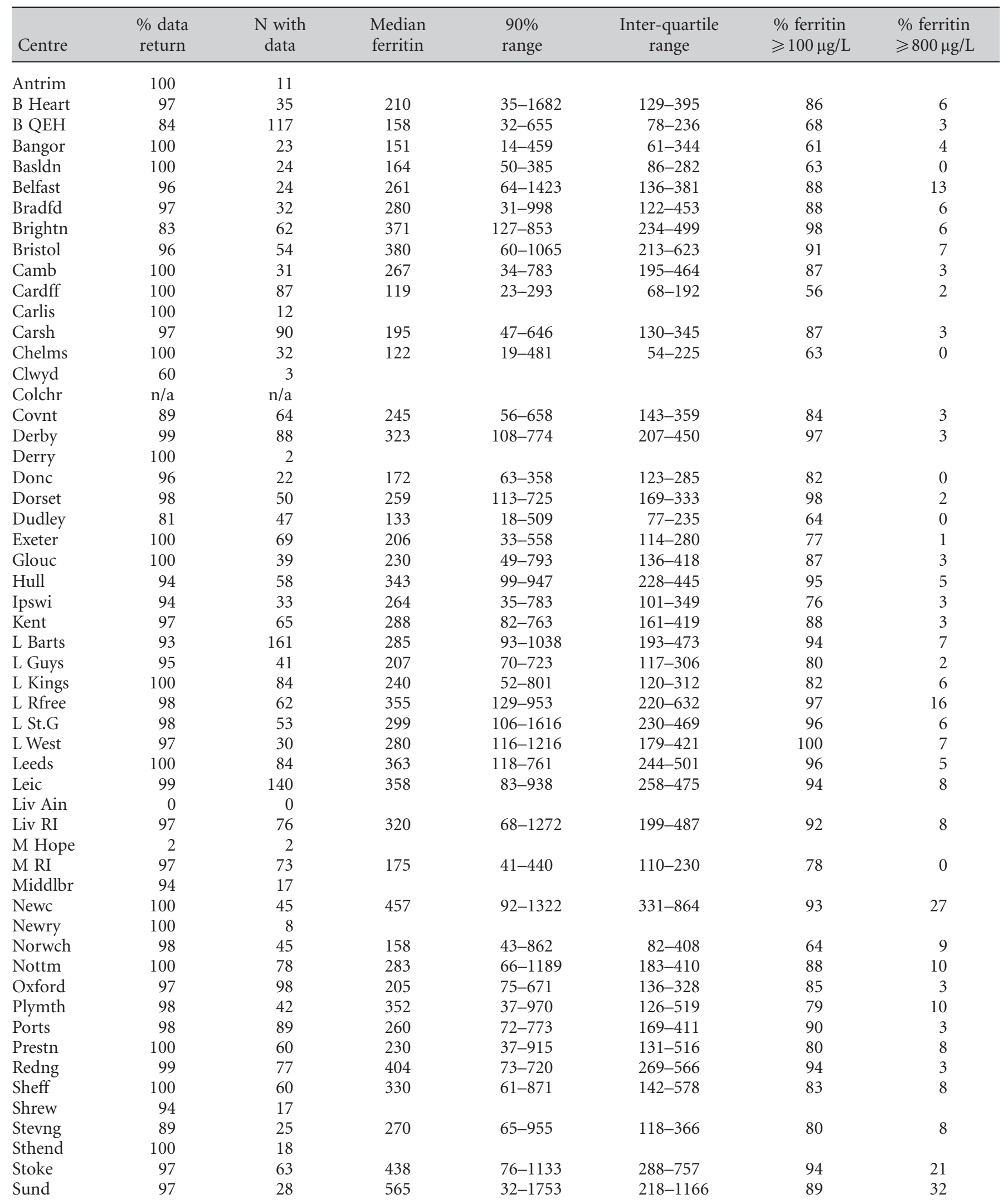


Table 8.5. Ferritin in PD patients in 2010

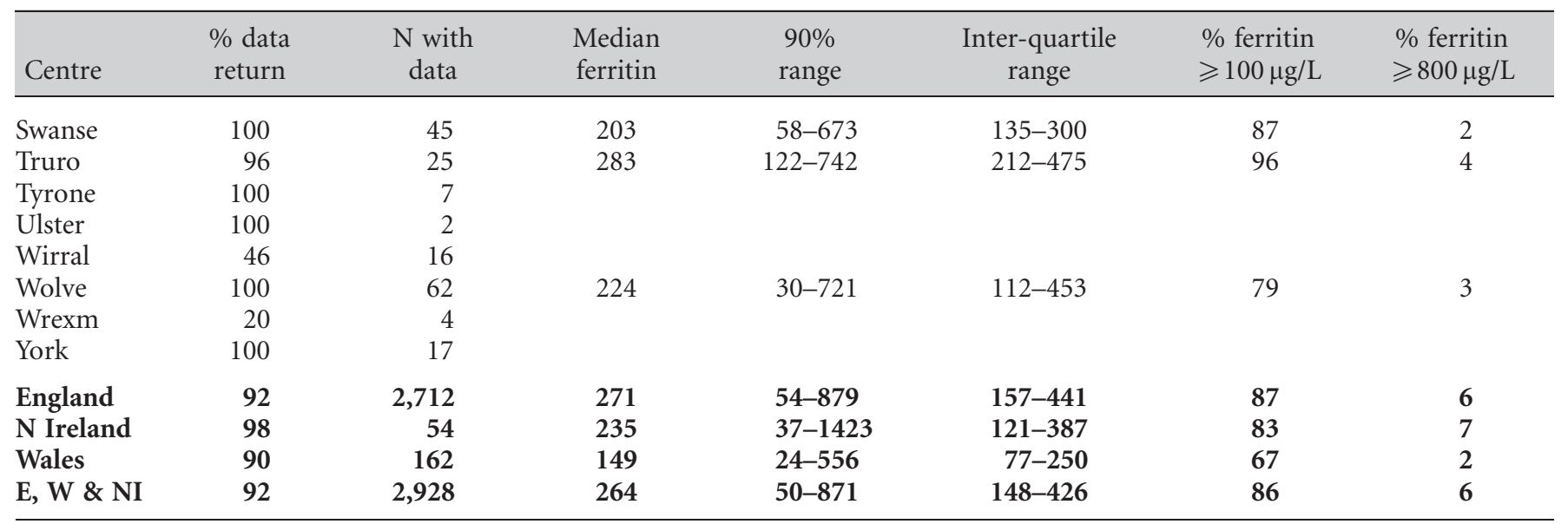

Blank cells $=$ centres excluded from analyses due to poor data completeness or low patient numbers $\mathrm{n} / \mathrm{a}=$ not applicable

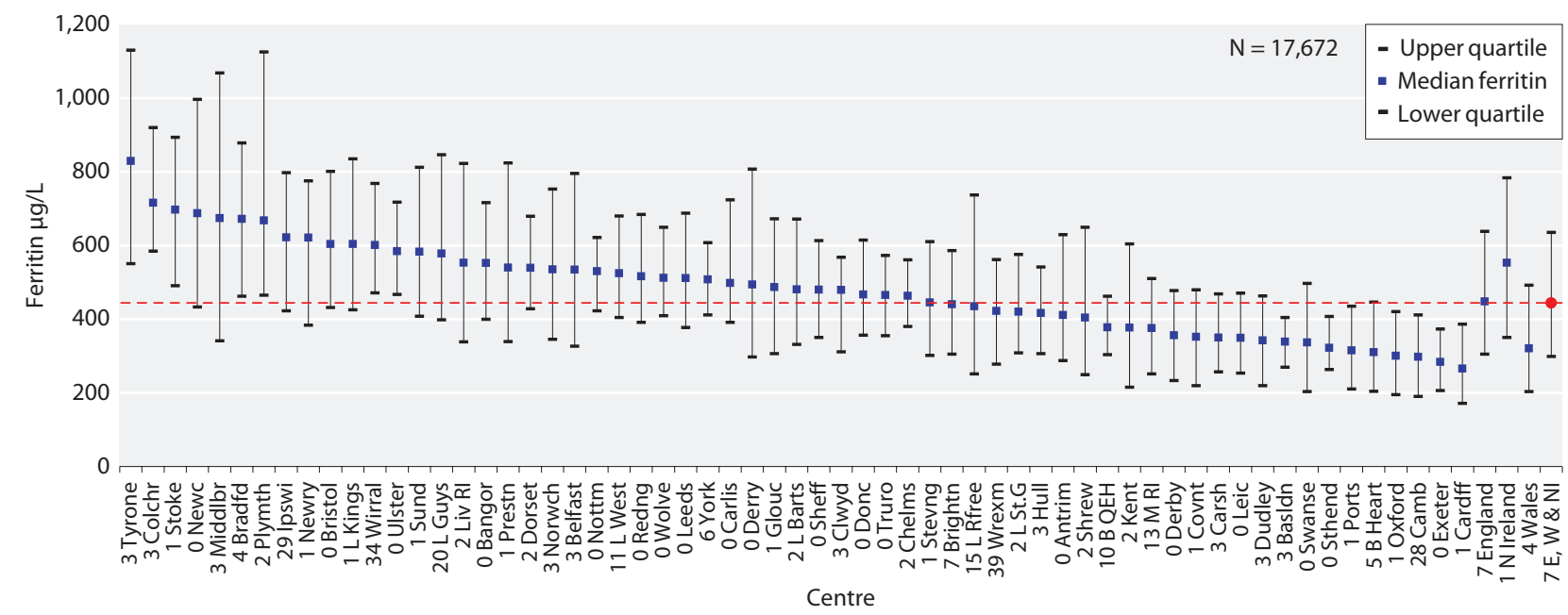

Fig. 8.29. Median ferritin in patients treated with HD by centre in 2010

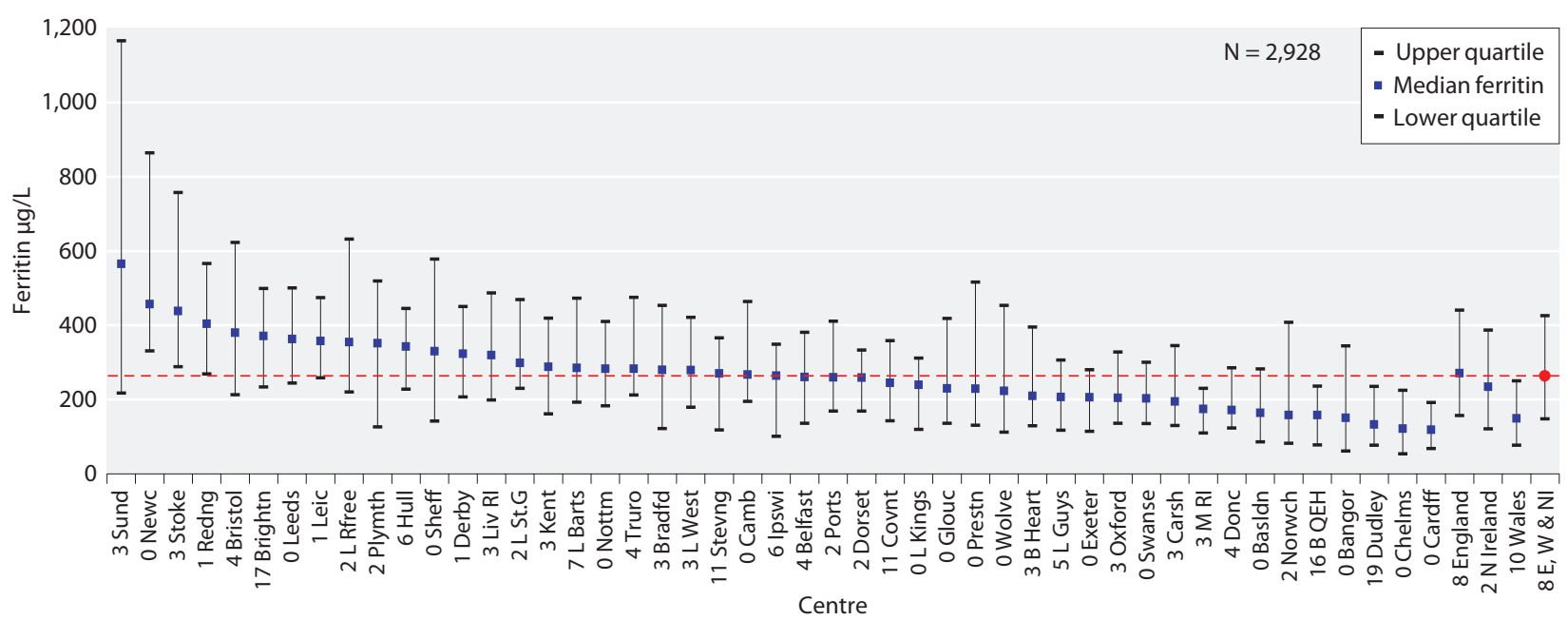

Fig. 8.30. Median ferritin in patients treated with PD by centre in 2010 


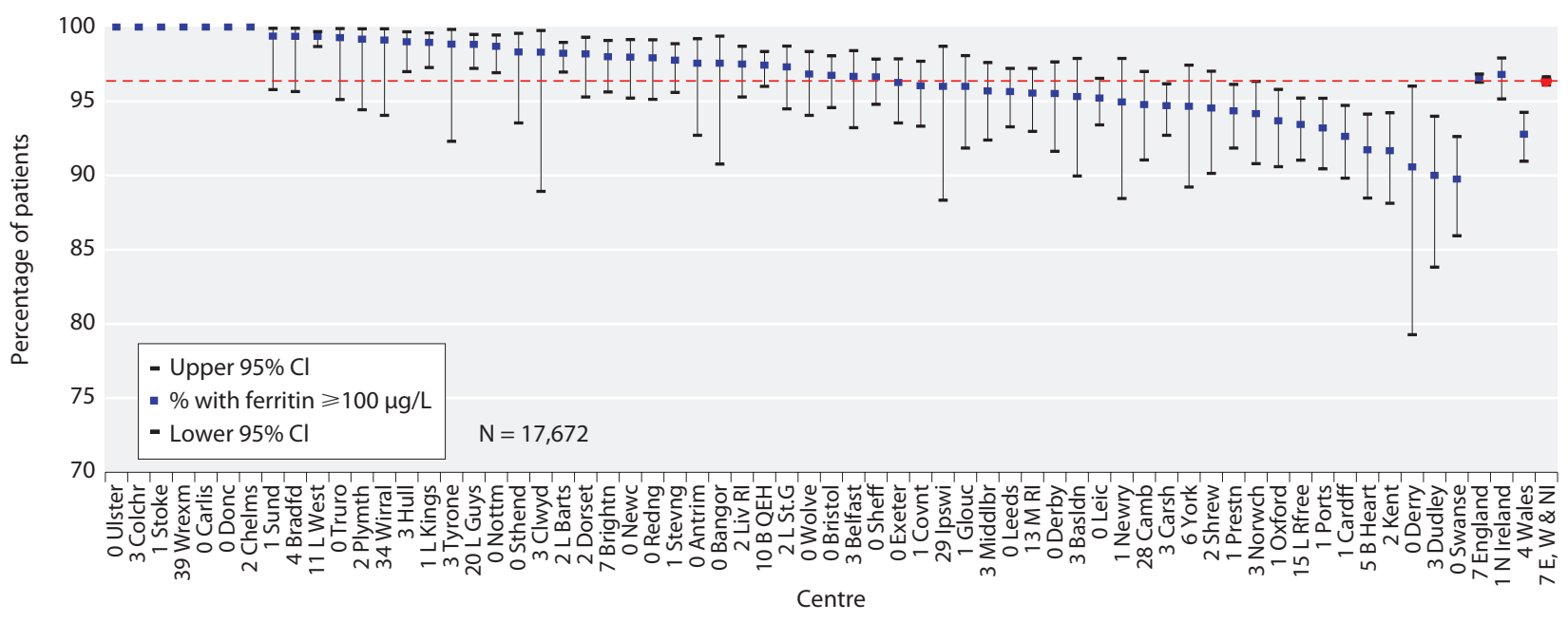

Fig. 8.31. Percentage of HD patients with ferritin $\geqslant 100 \mu \mathrm{g} / \mathrm{L}$ by centre in 2010

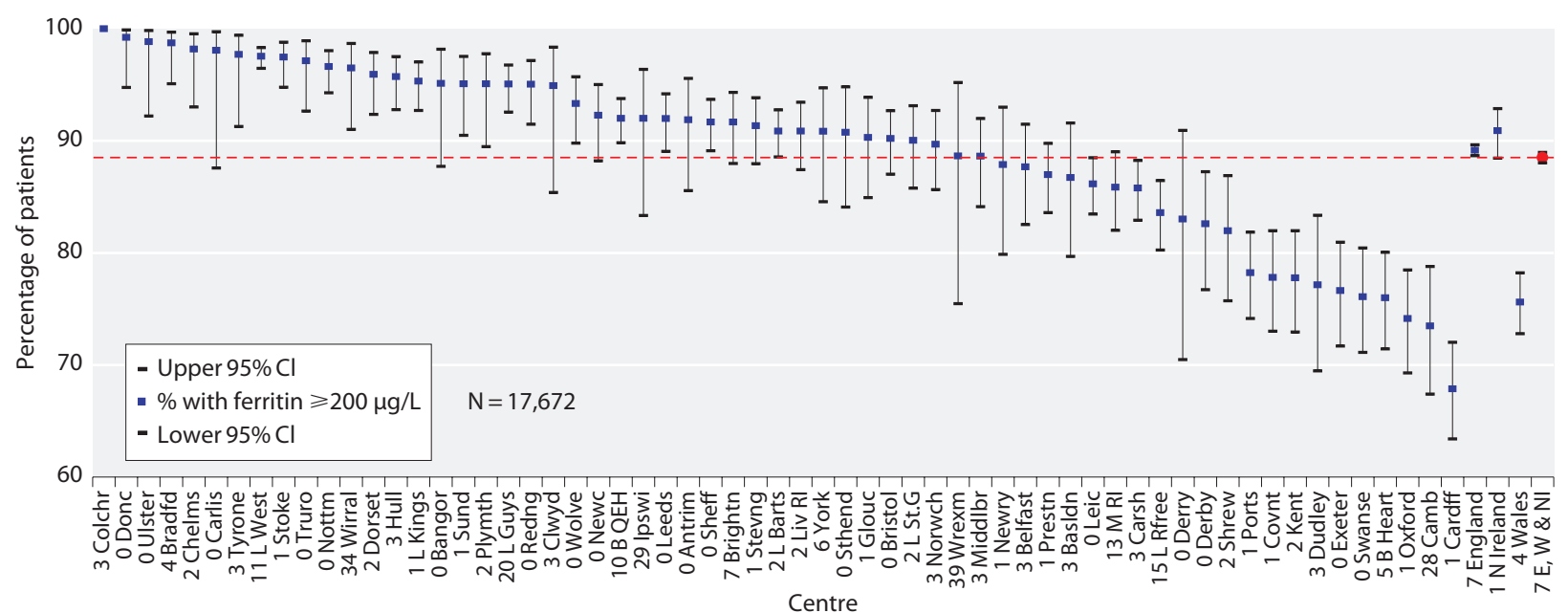

Fig. 8.32. Percentage of HD patients with ferritin $\geqslant 200 \mu \mathrm{g} / \mathrm{L}$ by centre in 2010

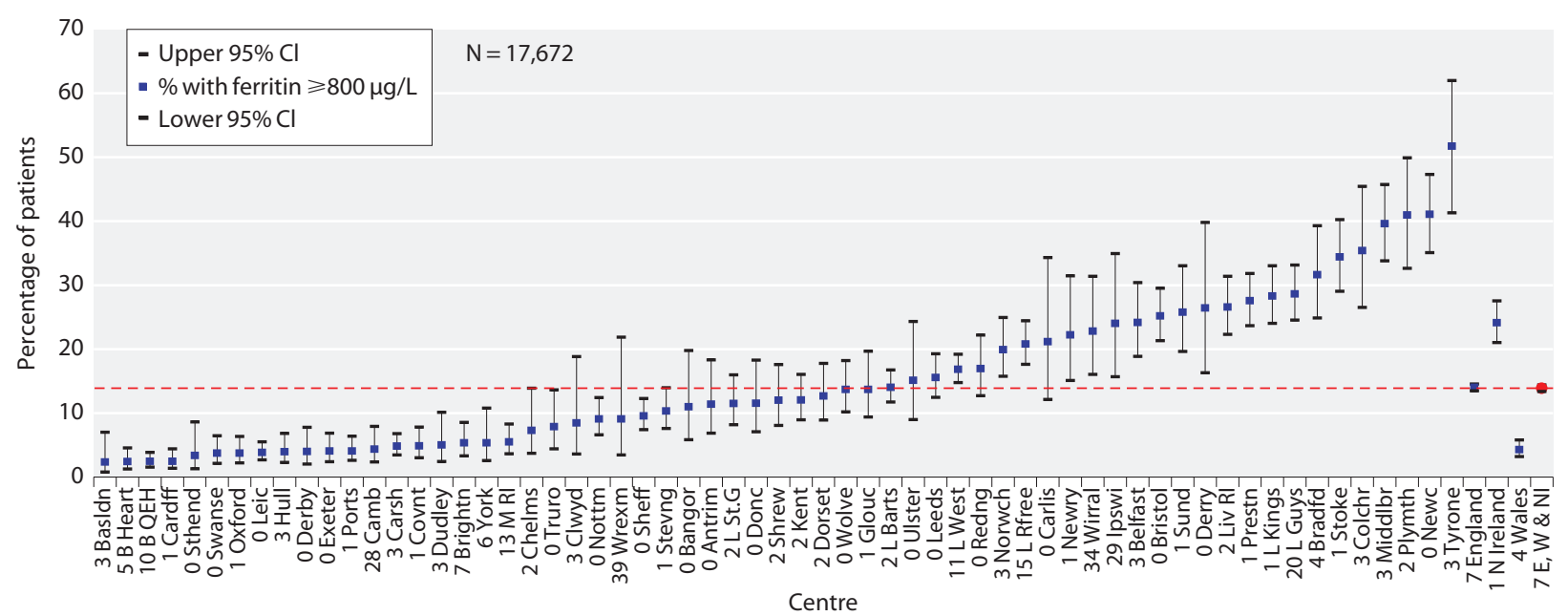

Fig. 8.33. Percentage of HD patients with ferritin $\geqslant 800 \mu \mathrm{g} / \mathrm{L}$ by centre in 2010 


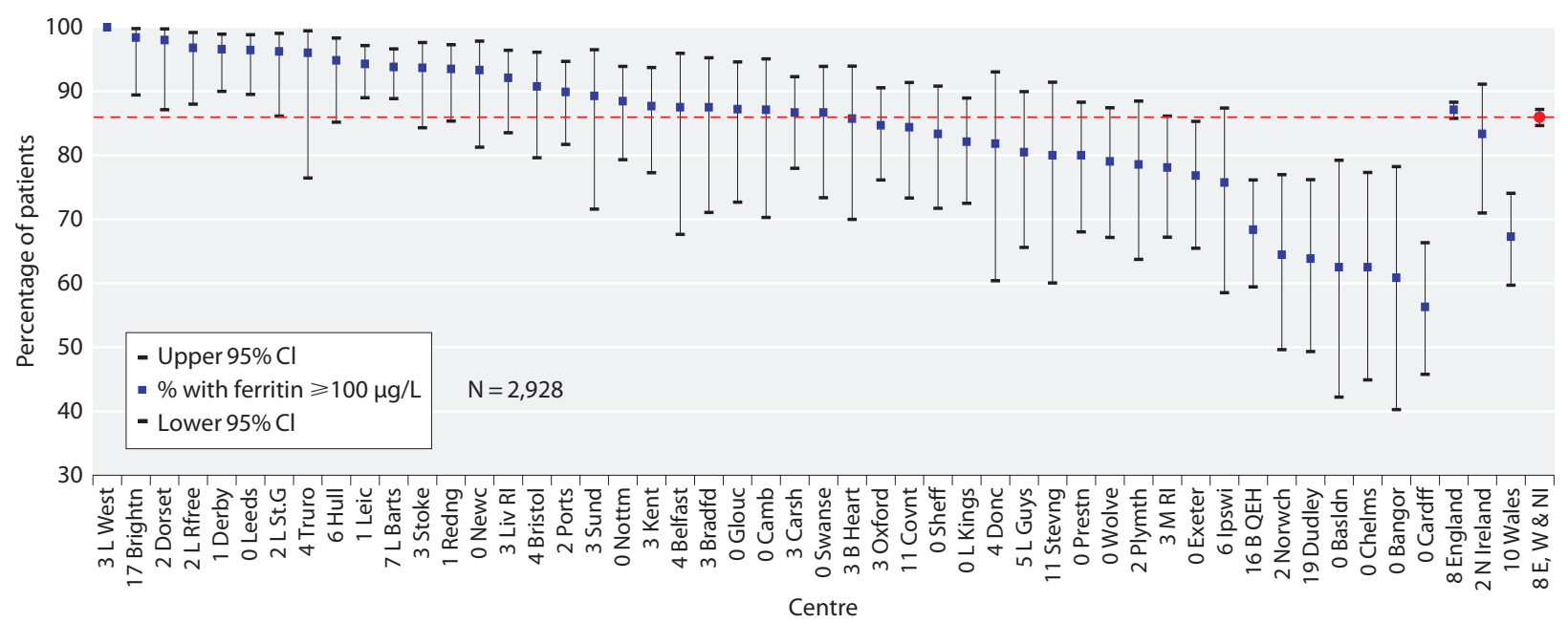

Fig. 8.34. Percentage of PD patients with ferritin $\geqslant 100 \mu \mathrm{g} / \mathrm{L}$ by centre in 2010

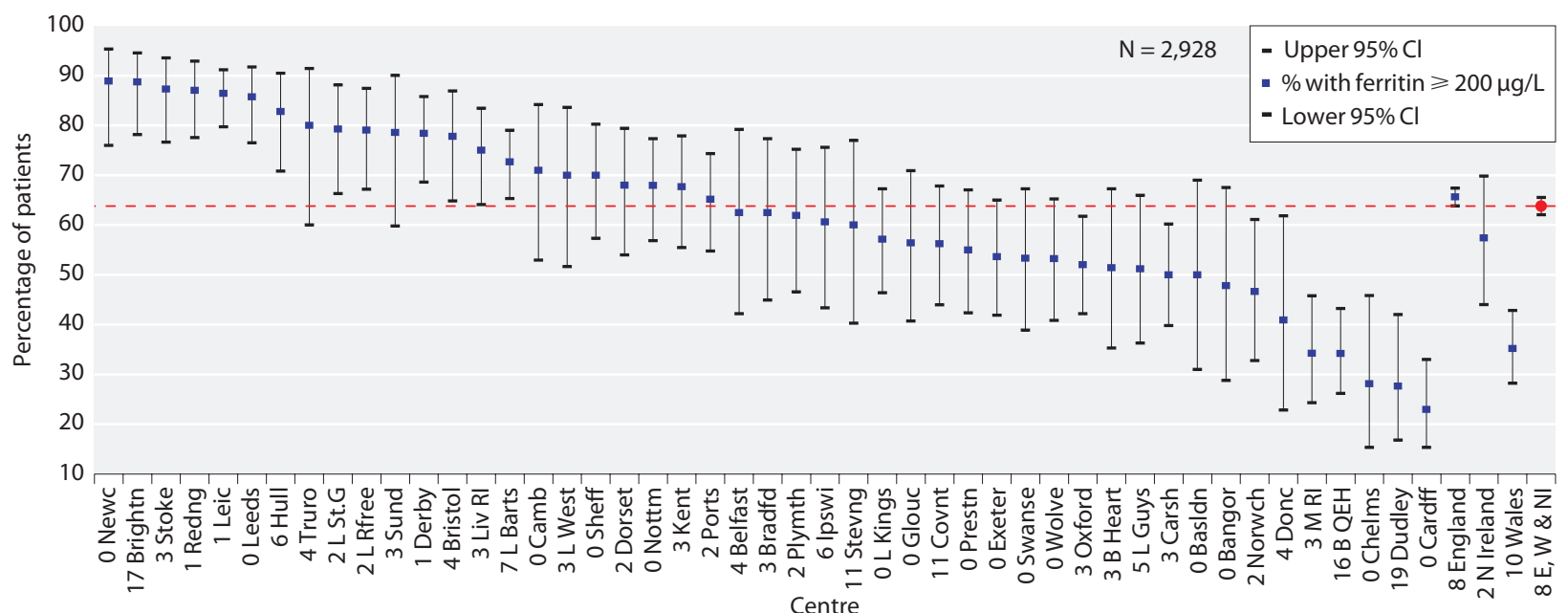

Fig. 8.35. Percentage of PD patients with ferritin $\geqslant 200 \mu \mathrm{g} / \mathrm{L}$ by centre in 2010

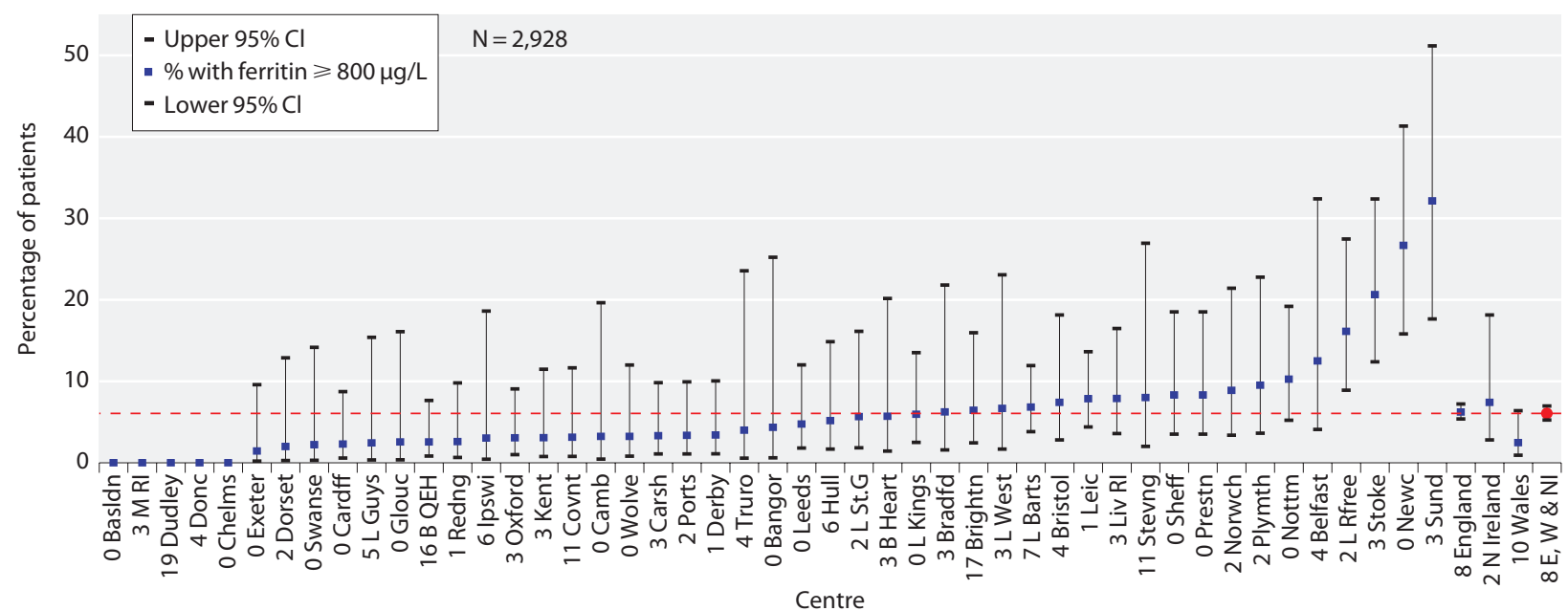

Fig. 8.36. Percentage of PD patients with ferritin $\geqslant 800 \mu \mathrm{g} / \mathrm{L}$ by centre in 2010 


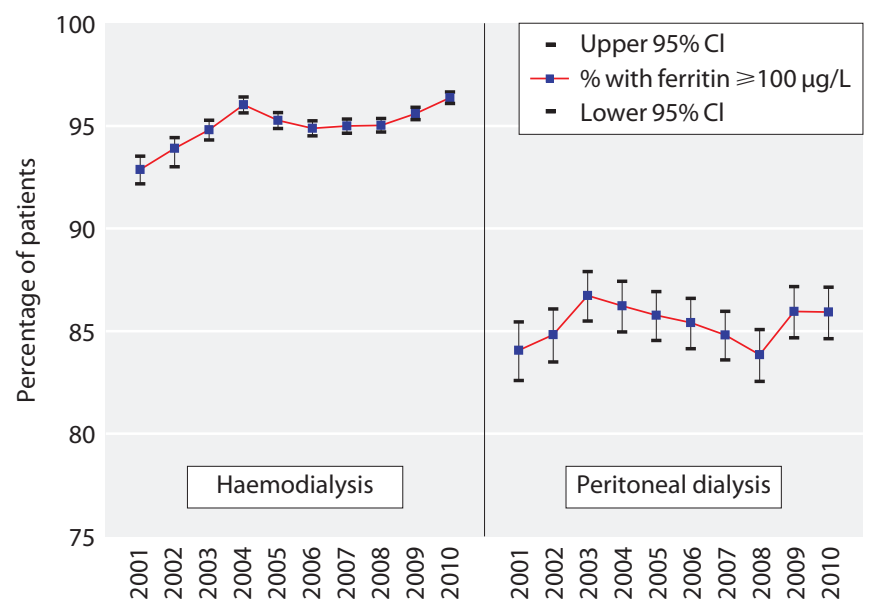

Fig. 8.37. Percentage of patients with ferritin $\geqslant 100 \mu \mathrm{g} / \mathrm{L}$ (20012010)

with the lowest possible doses are desirable. Furthermore, recent studies such as the CREATE and CHOIR studies suggest that driving the haemoglobin levels above $13 \mathrm{~g} / \mathrm{dl}$ and/or high doses of ESAs per se may be associated with an excess of cardiovascular risk compared to the comparator groups in these and other studies $[11,12]$. Table 8.6 shows the percentage of patients treated and the dose of ESA given in $\mathrm{HD}$ patients. Equivalent data for $\mathrm{PD}$ patients are shown in table 8.7. As shown in previous reports there is substantial variation in the average doses of ESA prescription used in UK dialysis units. The median dose for prevalent HD patients

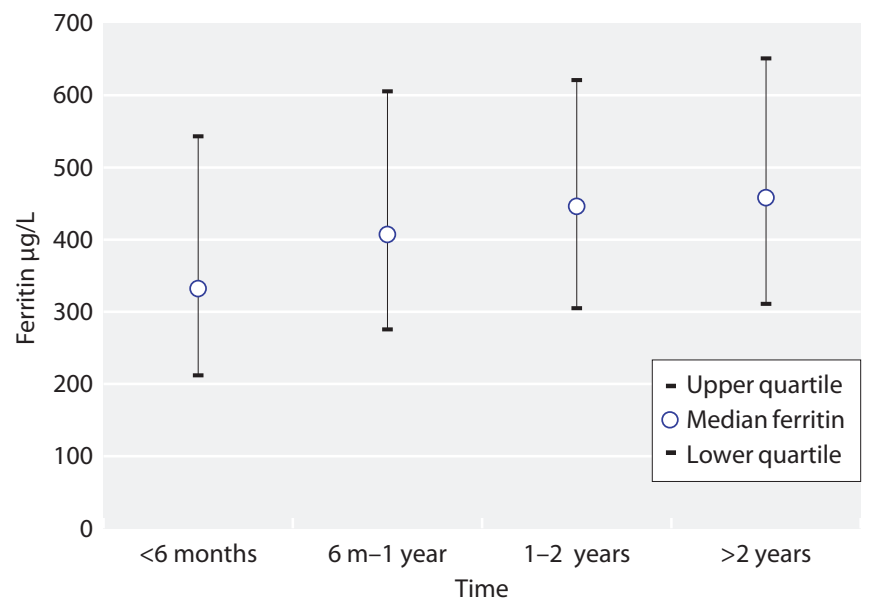

Fig. 8.39. Median ferritin by length of time on RRT in patients treated with HD in 2010

varied from 4,000 to 12,000 IU/week. In PD patients, in whom target haemoglobin can be achieved with substantially less agent, the median dose varied from $3,000-8,000$ IU/week. The mean doses for 2010 prevalent patients in England, Wales and Northern Ireland were 9,020 IU/week for $\mathrm{HD}$ and 6,202 IU/week for PD patients.

\section{ESA prescription: age and modality associations}

The proportion of patients on an ESA was higher for HD (91\%) than PD (74\%) and this difference was present and similar across all age bands (figure 8.41). The percentage of the whole cohort which maintained
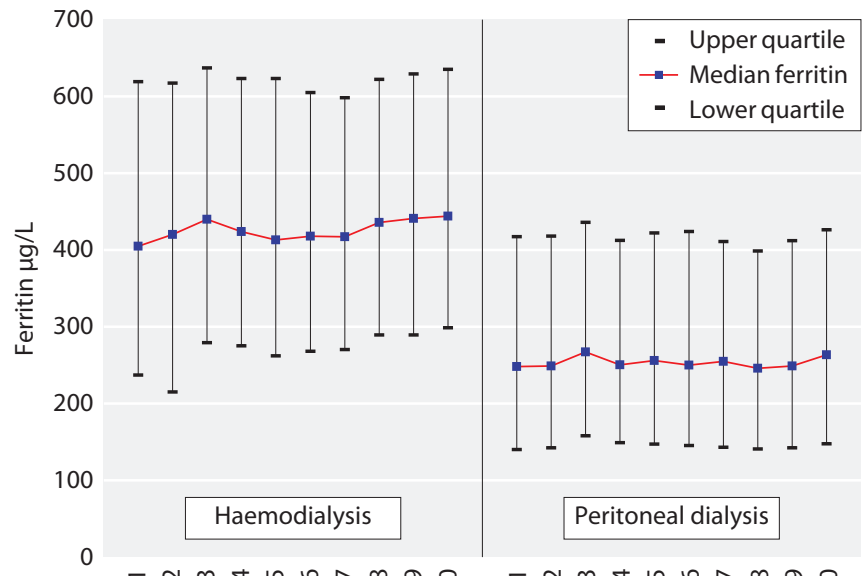

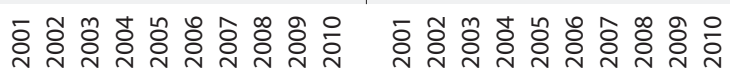

Fig. 8.38. Median ferritin of prevalent patients (2001-2010)

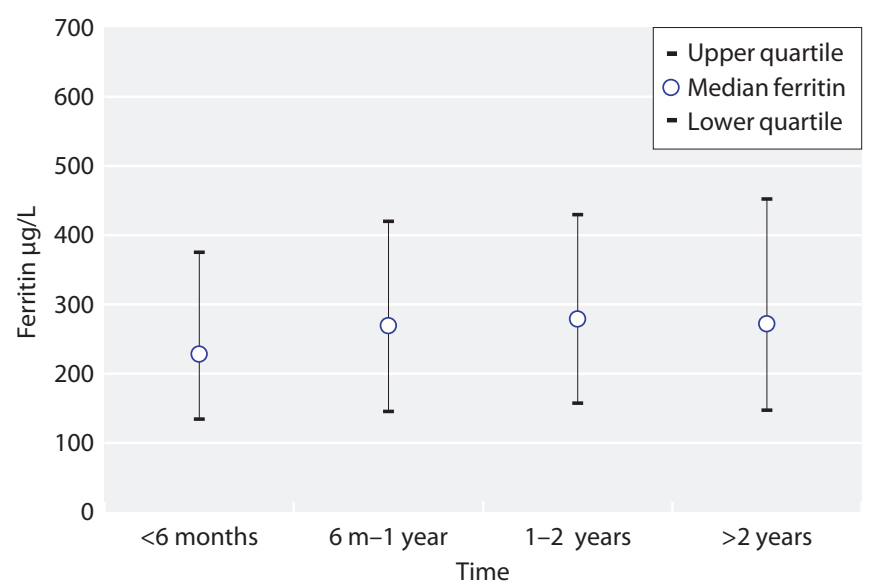

Fig. 8.40. Median ferritin by length of time on RRT in patients treated with PD in 2010 
Table 8.6. ESA prescribing in HD patients in 2010

\begin{tabular}{|c|c|c|c|c|c|c|c|}
\hline Centre & $\begin{array}{l}\mathrm{N} \text { in ESA } \\
\text { data file }\end{array}$ & $\begin{array}{l}\% \text { on } \\
\text { ESA }\end{array}$ & $\begin{array}{l}\mathrm{N} \text { on } \\
\text { ESA }\end{array}$ & $\begin{array}{l}\text { \% with } \\
\text { dose data }\end{array}$ & $\begin{array}{l}\text { Mean weekly dose for } \\
\text { pts on ESA (IU/week) }\end{array}$ & $\begin{array}{l}\text { Median weekly dose for } \\
\text { pts on ESA (IU/week) }\end{array}$ & $\begin{array}{l}\% \text { with } \mathrm{Hb} \geqslant 10 \mathrm{~g} / \mathrm{dl} \\
\text { and not on } \mathrm{ESA}\end{array}$ \\
\hline Antrim & 123 & 94 & 116 & 100 & 9,129 & 8,000 & 6 \\
\hline Basldn & 132 & 91 & 120 & 100 & 8,988 & 8,000 & 7 \\
\hline Belfast & 217 & 90 & 196 & 100 & 7,849 & 6,000 & 8 \\
\hline Bradfd & 165 & 95 & 157 & 99 & 7,401 & 6,000 & 3 \\
\hline Covnt & 332 & 90 & 298 & 100 & 12,939 & 12,000 & 8 \\
\hline Derry & 53 & 92 & 49 & 100 & 10,265 & 9,000 & 6 \\
\hline Donc & 130 & 92 & 120 & 100 & 9,475 & 8,000 & 7 \\
\hline Exeter & 322 & 96 & 309 & 100 & 8,894 & 8,000 & 4 \\
\hline Glouc & 173 & 100 & 173 & 0 & & & 0 \\
\hline Ipswi & 106 & 89 & 94 & 89 & 8,560 & 8,000 & 9 \\
\hline Middlbr & 263 & 78 & 206 & 100 & 6,461 & 6,000 & 17 \\
\hline Newc & 247 & 89 & 220 & 100 & 9,966 & 7,600 & 9 \\
\hline Newry & 100 & 95 & 95 & 100 & 6,202 & 4,000 & 5 \\
\hline Norwch & 299 & 92 & 276 & 100 & 9,201 & 8,000 & 7 \\
\hline Nottm & 385 & 93 & 358 & 87 & 10,806 & 9,000 & 6 \\
\hline Oxford & 352 & 90 & 317 & 100 & 11,565 & 8,000 & 10 \\
\hline Prestn & 467 & 86 & 401 & 9 & & & 11 \\
\hline Redng & 243 & 93 & 226 & 0 & & & 6 \\
\hline Sheff & 565 & 88 & 495 & 99 & 9,408 & 8,000 & 12 \\
\hline Shrew & 186 & 91 & 170 & 100 & 8,341 & 8,000 & 8 \\
\hline Sthend & 119 & 87 & 104 & 100 & 11,519 & 10,000 & 12 \\
\hline Truro & 140 & 100 & 140 & 94 & 7,180 & 5,538 & 0 \\
\hline Wales & 72 & 97 & 70 & 100 & 7,557 & 6,000 & 1 \\
\hline $\mathrm{E}, \mathrm{W} \& \mathrm{NI}$ & 8,598 & 91 & 7,843 & 89 & 9,020 & 8,000 & 8 \\
\hline
\end{tabular}

Blank cells denote centres excluded from analyses due to missing or very incomplete dosage data

a $\mathrm{Hb} \geqslant 10 \mathrm{~g} / \mathrm{dl}$ without requiring ESA (by age band and modality) is shown in figure 8.42.

Figure 8.43 shows the percentage of anaemic patients $(\mathrm{Hb}<10.0 \mathrm{~g} / \mathrm{dl})$ receiving an ESA. A minority of patients had a $\mathrm{Hb}<10 \mathrm{~g} / \mathrm{dl}$ and appeared to not be receiving ESA therapy. There are several potential explanations for this including some patients being declared unresponsive to ESA therapy and therefore no longer being on treatment, some individuals may have just become anaemic and not yet started therapy, others may have been on ESA treatment but not had it recorded and other patients may have decided not to use ESA because of a history of malignancy.

\section{ESA prescription and gender}

Provision of ESA by age and gender for HD and PD patients is shown in figures 8.44 and 8.45 . For both modalities across all age ranges, a higher percentage of females were on ESA treatment. In HD patients, 94\% of females were receiving ESA therapy compared to $89 \%$ of males. In PD patients, $77 \%$ of females compared to $72 \%$ of males were on ESA treatment. 
Table 8.7. ESA prescribing in PD patients in 2010

\begin{tabular}{|c|c|c|c|c|c|c|c|}
\hline Centre & $\begin{array}{l}\mathrm{N} \text { in } \mathrm{ESA} \\
\text { data file }\end{array}$ & $\begin{array}{l}\% \text { on } \\
\text { ESA }\end{array}$ & $\begin{array}{l}\mathrm{N} \text { on } \\
\mathrm{ESA}\end{array}$ & $\begin{array}{l}\% \text { with } \\
\text { dose data }\end{array}$ & $\begin{array}{l}\text { Mean weekly dose for } \\
\text { pts on ESA (IU/week) }\end{array}$ & $\begin{array}{l}\text { Median weekly dose for } \\
\text { pts on ESA (IU/week) }\end{array}$ & $\begin{array}{l}\% \text { with } \mathrm{Hb} \geqslant 10 \mathrm{~g} / \mathrm{dl} \\
\text { and not on } \mathrm{ESA}\end{array}$ \\
\hline Antrim & 11 & & & & & & \\
\hline Bangor & 23 & 61 & 14 & & & & 39 \\
\hline Basldn & 24 & 50 & 12 & 100 & 6,083 & 5,000 & 46 \\
\hline Belfast & 25 & 64 & 16 & 100 & 5,500 & 4,500 & 33 \\
\hline Camb & 31 & 68 & 21 & 100 & 8,210 & 5,600 & 29 \\
\hline Carlis & 12 & & & & & & \\
\hline Chelms & 32 & 84 & 27 & 100 & 4,963 & 4,000 & 16 \\
\hline Covnt & 72 & 75 & 54 & 100 & 9,622 & 8,000 & 23 \\
\hline Derry & 2 & & & & & & \\
\hline Donc & 23 & 83 & 19 & 100 & 5,368 & 4,000 & 17 \\
\hline Leeds & 84 & 88 & 74 & 99 & 4,945 & 4,000 & 11 \\
\hline Leic & 141 & 84 & 118 & 100 & 4,638 & 4,000 & 16 \\
\hline Liv RI & 78 & 78 & 61 & 100 & 9,997 & 8,000 & 21 \\
\hline Middlbr & 18 & & & & & & \\
\hline Norwch & 46 & 57 & 26 & 100 & 3,954 & 4,000 & 39 \\
\hline Nottm & 78 & 69 & 54 & 0 & & & 29 \\
\hline Oxford & 101 & 74 & 75 & 100 & 9,027 & 8,000 & 22 \\
\hline Plymth & 43 & 63 & 27 & 100 & 6,148 & 6,000 & 33 \\
\hline Prestn & 60 & 57 & 34 & 0 & & & 37 \\
\hline Redng & 78 & 73 & 57 & 0 & & & 23 \\
\hline Sheff & 60 & 65 & 39 & 100 & 6,551 & 4,000 & 35 \\
\hline Shrew & 18 & & & & & & \\
\hline England & 1,438 & 75 & 1,081 & 82 & 6,318 & 4,000 & 23 \\
\hline N Ireland & 47 & 66 & 31 & 100 & 5,226 & 3,000 & 32 \\
\hline Wales & 68 & 60 & 41 & & & & 40 \\
\hline $\mathrm{E}, \mathrm{W} \& \mathrm{NI}$ & 1,553 & 74 & 1,153 & 81 & 6,202 & 4,000 & 24 \\
\hline
\end{tabular}

Blank cells denote centres excluded from analyses due to low patient numbers or very incomplete dosage data

ESAs and time on renal replacement therapy

The percentage of patients on ESA by time on RRT and dialysis modality is shown in figure 8.46. This is a cross-sectional analysis at the final quarter of 2010. Patients who had previously changed RRT modality were still included in this analysis. The proportion of $\mathrm{PD}$ patients requiring ESA rises with duration of RRT from $73 \%$ after 1 year of $\mathrm{PD}$, to $78 \%$ after 10 or more years. This almost certainly reflects the loss of residual renal function. For at least the first 10 years on RRT, a greater percentage of HD patients are receiving ESA treatment than patients on $\mathrm{PD}$ at any given time point.

ESA dose and success with guideline compliance

There is no significant relationship between centres' mean ESA dose and median $\mathrm{Hb}$ for $\mathrm{HD}$ patients (figure 8.47) or compliance with the EPBG minimum 


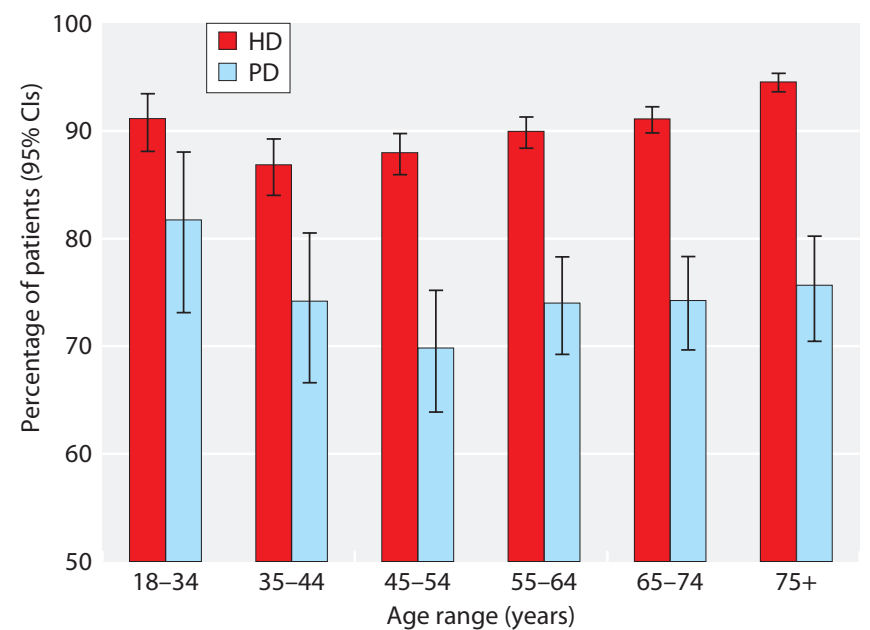

Fig. 8.41. Percentage of dialysis patients on ESA, by age group and treatment modality (2010)

standard for $\mathrm{Hb}$ in $\mathrm{HD}$ patients (figure 8.48). This is not surprising as the most anaemic patients and those least responsive to ESAs are those given the biggest doses. Figure 8.49 shows the frequency distribution of weekly ESA dose by treatment modality.

It is known that not all patients treated with dialysis who have a $\mathrm{Hb}$ above $12 \mathrm{~g} / \mathrm{dl}(\mathrm{HD})$ or $12.5 \mathrm{~g} / \mathrm{dl}(\mathrm{PD})$ are receiving ESA. It has been suggested that it may be inappropriate to include those patients not receiving ESA within the group not meeting this RA target. There are two reasons: firstly, the high $\mathrm{Hb}$ remains outside the control of the clinician, and secondly, the recent trials suggesting that it may be detrimental to

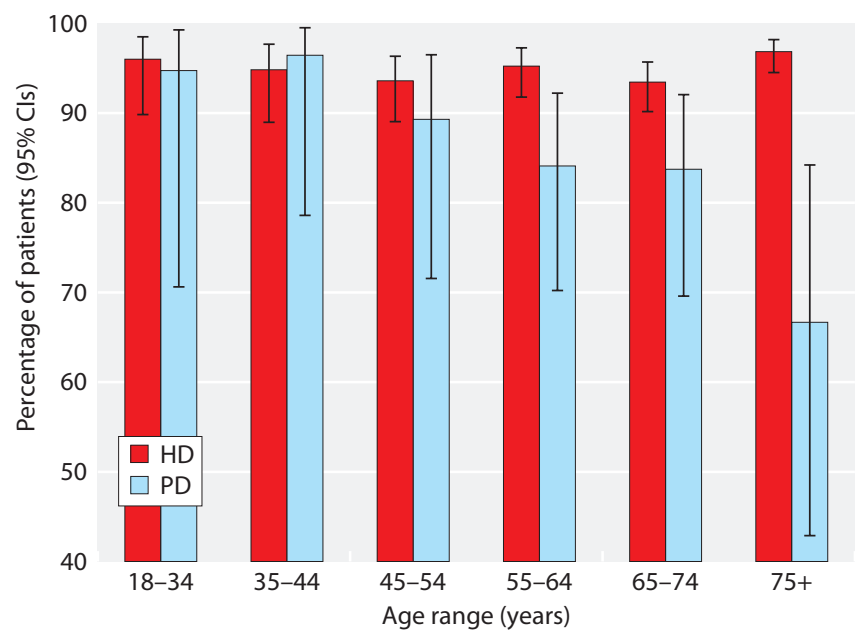

Fig. 8.43. Percentage of patients with $\mathrm{Hb}<10 \mathrm{~g} / \mathrm{dl}$ who are on ESA, by age group and treatment modality (2010)

achieve a high $\mathrm{Hb}$ in renal patients were based only upon patients treated with ESAs [11, 12].

Figures 8.50 and 8.51 show the percentages of $\mathrm{HD}$ and $\mathrm{PD}$ patients in each centre whose $\mathrm{Hb}$ lies above, within or below the RA guidelines of 10-12 g/dl (HD) or 10.5$12.5 \mathrm{~g} / \mathrm{dl}$ (PD). These charts also show the proportion of patients with a $\mathrm{Hb}$ above the upper limit who were receiving, or were not receiving ESAs. These analyses are restricted to the centres with acceptable ESA returns as stipulated above. These figures show that $31.1 \%$ of HD patients had a $\mathrm{Hb}>12 \mathrm{~g} / \mathrm{dl}$. Most of these patients $(84.8 \%)$ were on ESAs. Over a quarter $(25.2 \%)$ of PD patients had a $\mathrm{Hb}>12.5 \mathrm{~g} / \mathrm{dl}$, but only $52.8 \%$ of these were on ESAs.

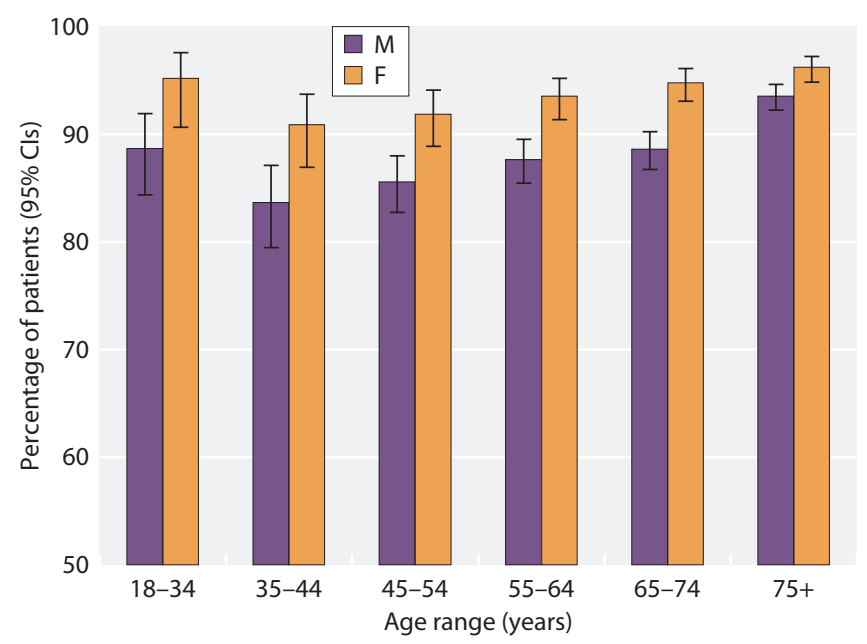

Fig. 8.44. Prescription of ESA by age and gender in patients treated with HD (2010) 


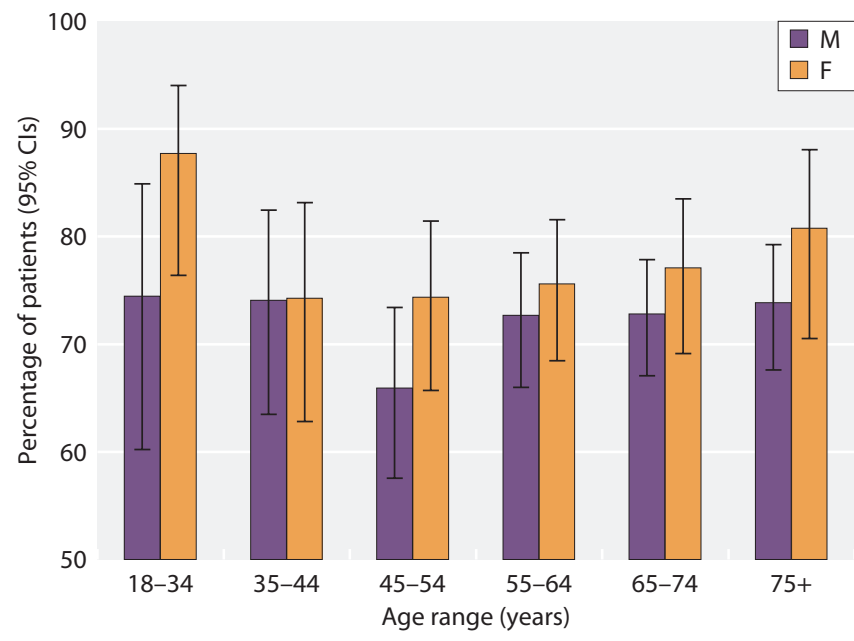

Fig. 8.45. Prescription of ESA by age and gender in patients treated with PD (2010)

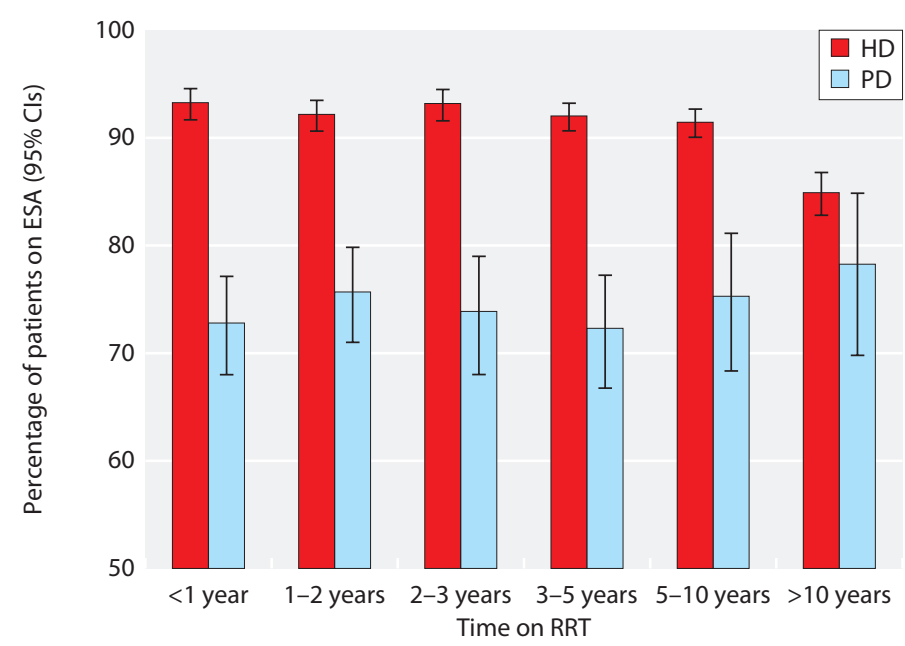

Fig. 8.46. Percentage of patients on ESA by time on RRT (2010)

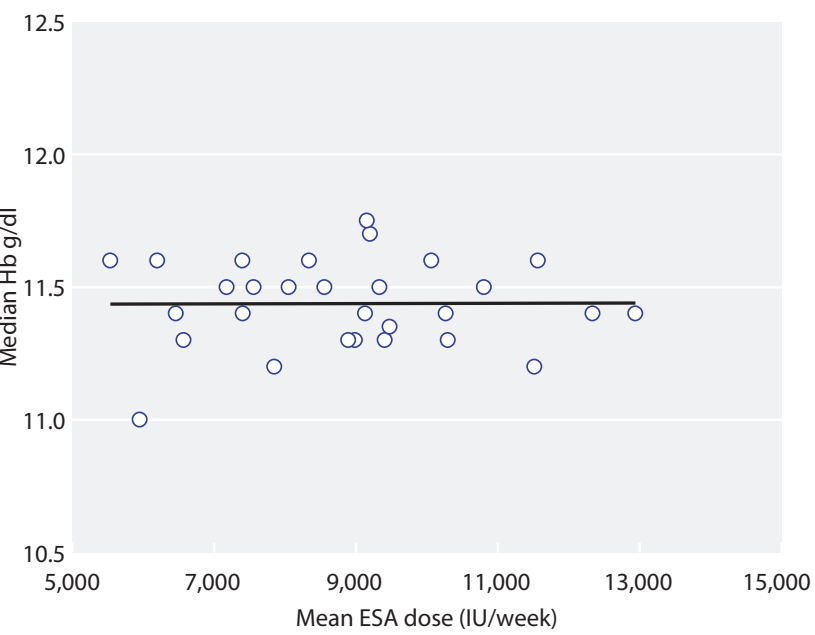

Fig. 8.47. Median $\mathrm{Hb}$ versus mean ESA dose in patients treated with HD by centre in 2010

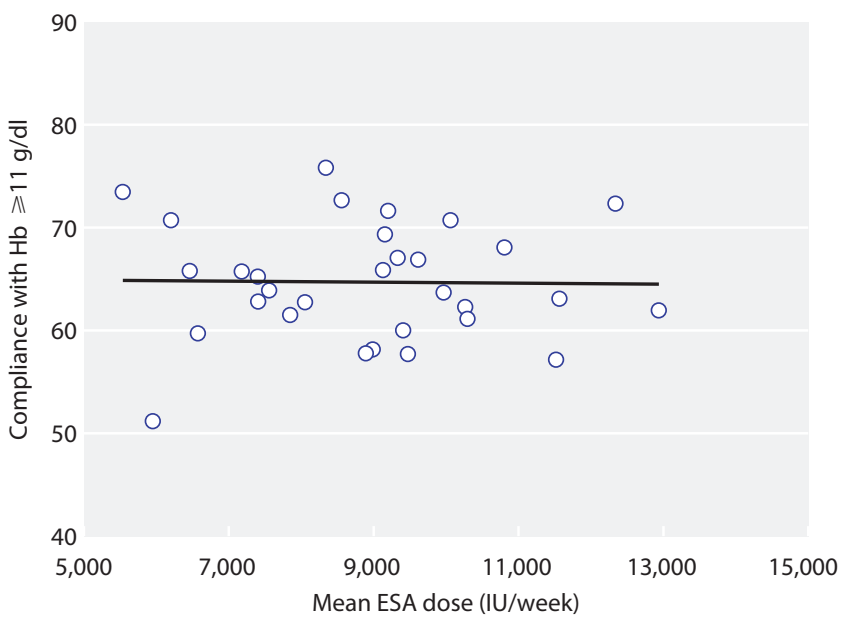

Fig. 8.48. Compliance with European Best Practice Guidelines versus mean ESA dose in patients treated with $\mathrm{HD}$ by centre in 2010

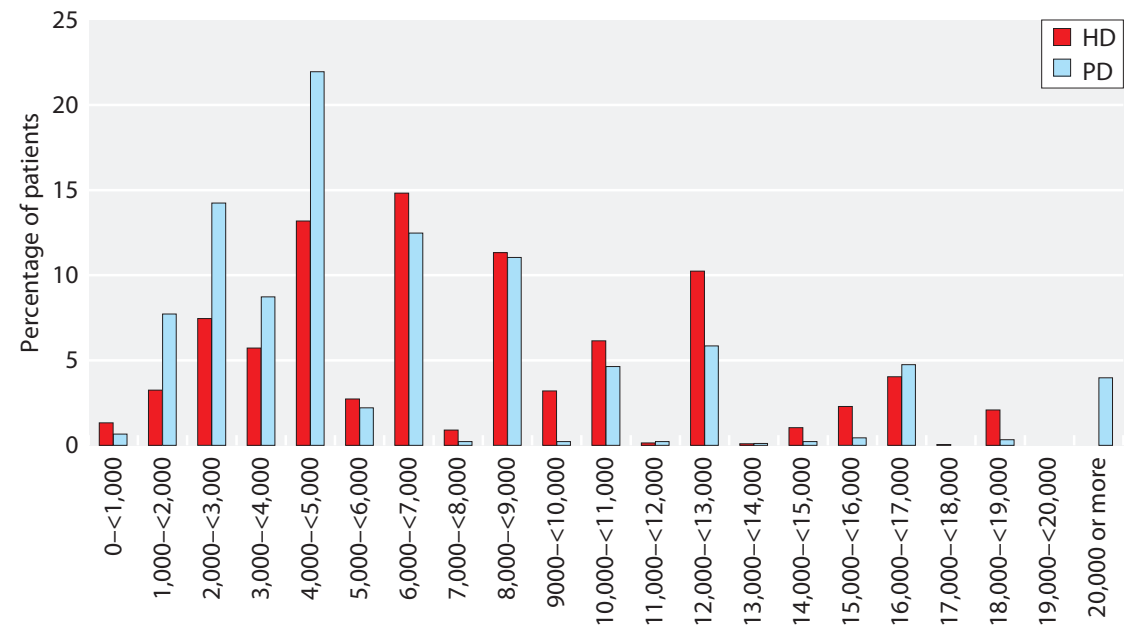

ESA dose (IU/week)
Fig. 8.49. Frequency distribution of weekly ESA dose in 2010 


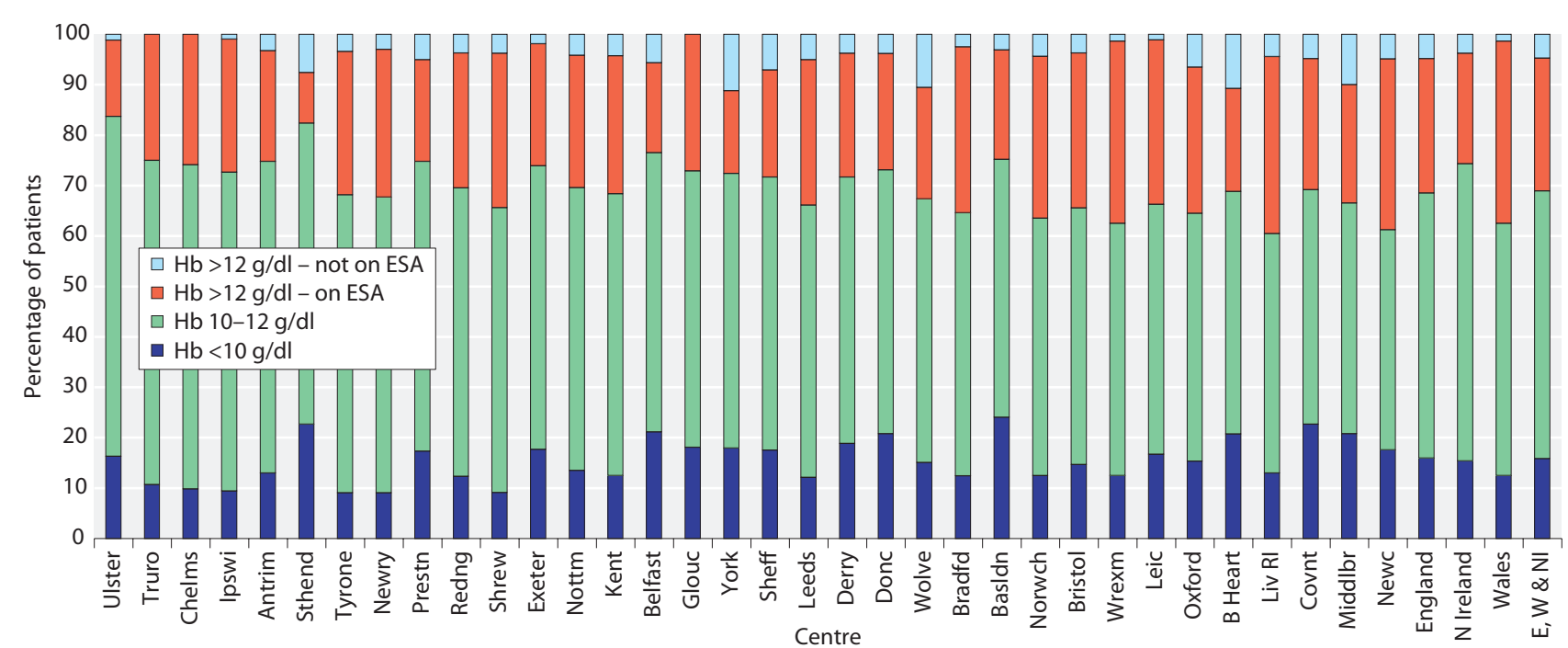

Fig. 8.50. Distribution of haemoglobin in patients treated with HD and the proportion of patients with $\mathrm{Hb}>12 \mathrm{~g} / \mathrm{dl}$ receiving ESA by centre in 2010

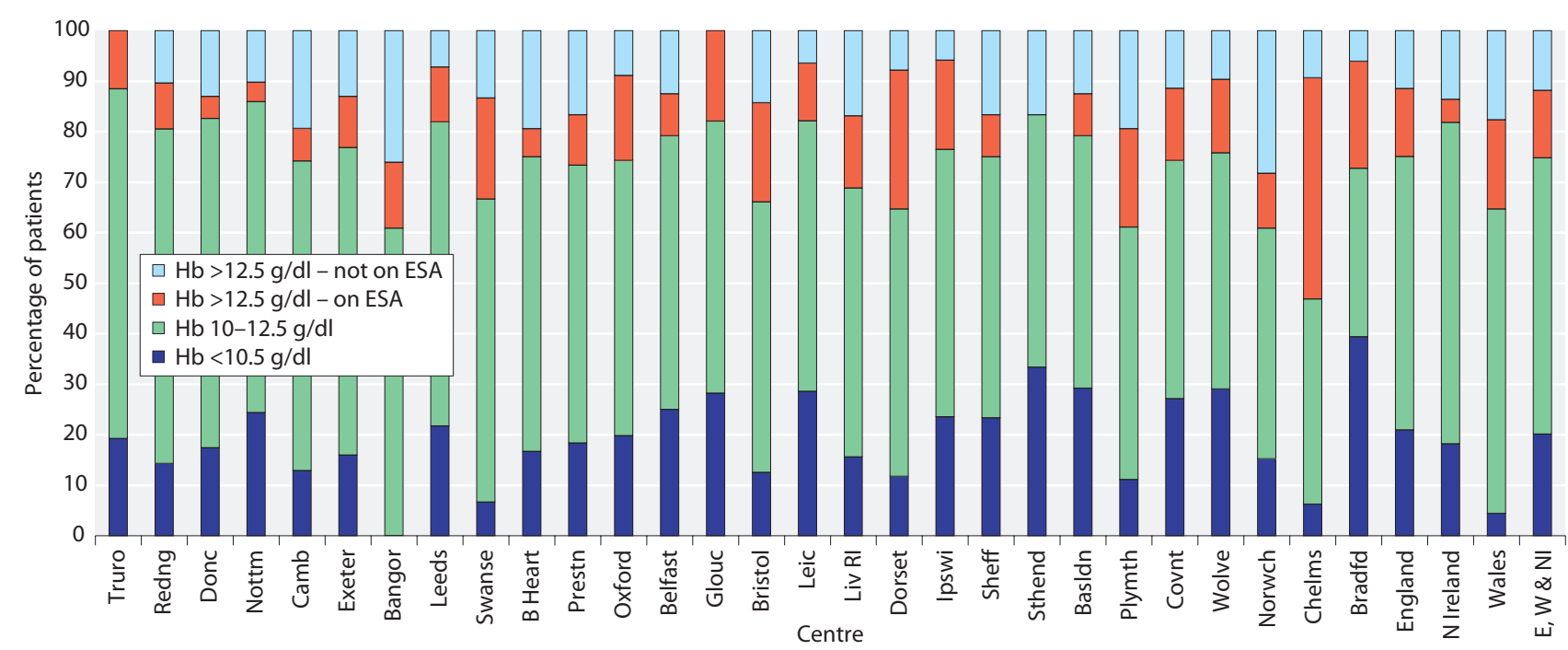

Fig. 8.51. Distribution of haemoglobin in patients treated with PD and the proportion of patients with $\mathrm{Hb}>12.5 \mathrm{~g} / \mathrm{dl}$ receiving ESA by centre in 2010

\section{Discussion}

Haemoglobin outcomes for patients on HD and PD in the UK were largely compliant with the RA minimum standard of $\mathrm{Hb} \geqslant 10.0 \mathrm{~g} / \mathrm{dl}(84.6 \%$ and $87.2 \%$ respectively). As would be anticipated, a greater proportion of prevalent patients $(85.0 \%)$ than incident patients (53.6\%) had a $\mathrm{Hb} \geqslant 10.0 \mathrm{~g} / \mathrm{dl}$ in 2010.

In the UK the median $\mathrm{Hb}$ of patients on $\mathrm{HD}$ was $11.5 \mathrm{~g} / \mathrm{dl}$ with an IQR of $10.5-12.3 \mathrm{~g} / \mathrm{dl}$, and the median
$\mathrm{Hb}$ of patients on $\mathrm{PD}$ was $11.6 \mathrm{~g} / \mathrm{dl}$ with an IQR of $10.6-12.5 \mathrm{~g} / \mathrm{dl}$. These UK averages are similar to those published in the last few UKRR reports.

Compliance with advice regarding iron stores as reflected by ferritin remained stable in the UK with $96 \%$ of HD patients and $86 \%$ of PD patients achieving a serum ferritin greater than $100 \mu \mathrm{g} / \mathrm{L}$.

The analysis of ESA usage was limited by incomplete data returns. From the available data, 91\% of $\mathrm{HD}$ patients and $74 \%$ of $\mathrm{PD}$ patients were on 
ESA treatment in England, Wales and Northern Ireland.

New guidelines introduced in $2010[8,9]$ mean that from the 15th Annual Report all RRT patients on ESA treatment will be measured against the $\mathrm{Hb}$ target of
$10-12 \mathrm{~g} / \mathrm{dl}$. It will be of interest how this affects median $\mathrm{Hb}$ levels and ESA use over the next few years.

Conflicts of interest: none

\section{References}

1 Department of Health Renal Team National Service Framework for Renal Services: Part One - Dialysis and transplantation. Department of Health, London. 2004

2 Renal Association. Treatment of adults and children with renal failure: standards and audit measures. 3rd Edition. Royal College of Physicians of London and the Renal Association, London. 2002

$\checkmark 3$ Revised European Best Practice Guidelines for the Management of Anaemia in Patients with Chronic Renal Failure. Nephrol Dial Transplant 2004;19:ii1-ii47

4 NKF-K/DOQI Clinical Practice Guidelines for Anemia of Chronic Kidney Disease: Update 2000. American journal of kidney diseases 2001;37:S182-S238

5 National Collaborating Centre for Chronic Conditions. Anaemia management in chronic kidney disease: national clinical guideline for management in adults and children. Royal College of Physicians, London. 2006

6 UK Renal Association Clinical Practice Guidelines Committee: Complications of CKD, 4th Edition. 2007. http://www.renal.org/pages/pages/ clinical-affairs/guidelines.php
7 Renal Association Clinical Practice Guidelines Committee: Haemodialysis, 5th Edition. 2009. http://www.renal.org/clinical/guidelinessection/ haemodialysis.aspx

8 UK Renal Association Clinical Practice Guidelines Committee: Anaemia of CKD, 5th Edition. 2010. http://www.renal.org/clinical/Guidelines Section/AnaemiaInCKD.aspx

9 National Institute for Health and Clinical Excellence (NICE). Anaemia management in people with chronic kidney disease (CG114), 2011. http://guidance.nice.org.uk/CG114

$10 \mathrm{http} / /$ :www.kdigo.org

11 Drueke TB, Locatelli F, Clyne N, Eckardt K-U, Macdougall IC, Tsakiris D, Burger H-U, Scherhag A, the CREATE Investigators: Normalization of Hemoglobin Level in Patients with Chronic Kidney Disease and Anemia. N Engl J Med 2006;355:2071-2084

12 Singh AK, Szczech L, Tang KL, Barnhart H, Sapp S, Wolfson M, Reddan $\mathrm{D}$, the CHOIR Investigators: Correction of Anemia with Epoetin Alfa in Chronic Kidney Disease. N Engl J Med 2006;355:2085-2098 